\title{
SIANN: Strain Identification by Alignment to Near Neighbors
}

\author{
Samuel S. Minot, Stephen D. Turner, Krista L. Ternus, and Dana R. Kadavy
}

January 9, 2014

\begin{abstract}
Next-generation sequencing is increasingly being used to study samples composed of mixtures of organisms, such as in clinical applications where the presence of a pathogen at very low abundance may be highly important. We present an analytical method (SIANN: Strain Identification by Alignment to Near Neighbors) specifically designed to rapidly detect a set of target organisms in mixed samples that achieves a high degree of species- and strain-specificity by aligning short sequence reads to the genomes of near neighbor organisms, as well as that of the target. Empirical benchmarking alongside the current state-of-the-art methods shows an extremely high Positive Predictive Value, even at very low abundances of the target organism in a mixed sample. SIANN is available as an Illumina BaseSpace app, as well as through Signature Science, LLC. SIANN results are presented in a streamlined report designed to be comprehensible to the non-specialist user, providing a powerful tool for rapid species detection in a mixed sample. By focusing on a set of (customizable) target organisms and their near neighbors, SIANN can operate quickly and with low computational requirements while delivering highly accurate results.
\end{abstract}

\section{Introduction}

There are many different methods that characterize the mixture of organisms present within a metagenomic dataset. Such datasets are generated when a complex environmental sample is processed by a "next-generation" high-throughput genome sequencing protocol, and they consist of large numbers of short nucleotide sequences. Each sequence represents a small fragment of a randomly selected genome from the very large collection of genomes present in the source sample. Those sequences indicate the presence of one organism or another according to their similarity to a set of known reference genomes. While a given sequence may be unique to one species, it also may be found in diverse organisms across the tree of life. Therefore, one analytical challenge (among many) is to take that collection of sequences (likely numbering in the millions) and accurately determine what species are present in the sample. Here we describe a novel method (SIANN: Strain Identification by Alignment to Near Neighbors) that is specifically designed to rapidly detect a set of targeted organisms from a metagenomic dataset by aligning reads to genomic regions that are unique at the strain or species level. 
SIANN: Strain Identification by Alignment to Near Neighbors

The analytical question motivating a particular piece of metagenomic bioinformatic analysis may vary widely by user and sample type (Segata, et al., 2013). For example, the function of the human gut microbiome may depend on the relative abundance of hundreds of species of bacteria and the types of metabolic genes they contain (Wu, et al., 2011; Schloissnig, et al., 2013). In contrast, the clinical treatment of a patient may depend on whether or not a particular virus, or a consortium of co-infecting pathogens, is/are detected in their blood. It is this second class of presence/absence questions that SIANN is designed to address. SIANN is appropriate for situations in which a user wants to know whether a particular organism or set of organisms is present in a sample, but isn't interested in the functions encoded in their genomes, the relative abundance of each organism, or any other more in-depth analysis.

\section{Methods}

\section{Approach}

Metagenomic classification methods are based on a wide variety of theoretical underpinnings. The basic varieties include alignment of reads to various nucleotide databases or exact matching to nucleotide or protein signature sequences (or kmers). A representative set of recent methods are described in Table 1 (also see Bazinet \& Cummings 2012).

\begin{tabular}{|c|c|c|}
\hline Name & Method & Reference \\
\hline MEGAN & Alignment to large nucleotide database & Huson, et al., 2011 \\
\hline PhymmBL & $\begin{array}{l}\text { Alignment to large nucleotide database } \\
\text { with interpolated Markov models }\end{array}$ & Brady \& Salzberg, 2011 \\
\hline Metaphyler & Alignment to clade-specific marker genes & Liu, et al., 2011 \\
\hline MetaPhIAn & Alignment to clade-specific marker genes & Segata, et al., 2012 \\
\hline LMAT & Nucleotide kmer matching & Ames, et al., 2013 \\
\hline Kraken & Nucleotide kmer matching & $\begin{array}{l}\text { Wood \& Salzberg, in } \\
\text { submission }\end{array}$ \\
\hline Sequedex & Protein kmer matching & Berendzen, et al., 2012 \\
\hline mOTU & Alignment to universal marker genes & Sunagawa, et al., 2013 \\
\hline Phylosift & $\begin{array}{l}\text { Insertion into reference nucleotide and } \\
\text { protein alignments }\end{array}$ & $\begin{array}{l}\text { Darling, et al., in } \\
\text { preparation }\end{array}$ \\
\hline
\end{tabular}

\section{Table 1. Summary of methods for metagenomic classification.}

Overall, these methods are designed to either classify individual reads to, and/or predict the total abundance of, clades (e.g. genus or species) across the entire tree of life. They generally require reference databases that are very large and/or require a large amount of processing to generate. The gap SIANN is designed to fill is when the entire tree of life is irrelevant, and only predefined subsets of organisms need to be detected. For an underlying method we chose read alignment to diagnostic genomic regions because the algorithms for read alignment are highly parallelizable and have been optimized heavily by the community at large (the current implementation of 
SIANN: Strain Identification by Alignment to Near Neighbors

SIANN uses bowtie2 [Langmead \& Salzberg, 2012] for the alignment function, but can be adapted to any alignment algorithm). This approach is distinct from using cladespecific marker genes (Segata, et al., 2012) because unique regions that are larger, smaller, or outside of genes can also be used. Furthermore, this approach supports the rapid construction of custom databases using reference genome sets that require only minimal user-supplied structure.

To understand the principle at work, consider a set of reads that have been aligned to the genomes of several strains belonging to two species. Some regions of those genomes are species-specific, some are strain-specific, and some are shared (Figure 1a). When a set of reads is aligned to those genomes such that each read is placed in as many locations as it has a match (at a reasonably stringent threshold), visual inspection of the distribution of reads yields an intuitive understanding of the true source organism as Species I/Strain B (Figure 1b). If Strain B were not present in the reference database, it would still be clear that the organism was an unknown strain of Species I.
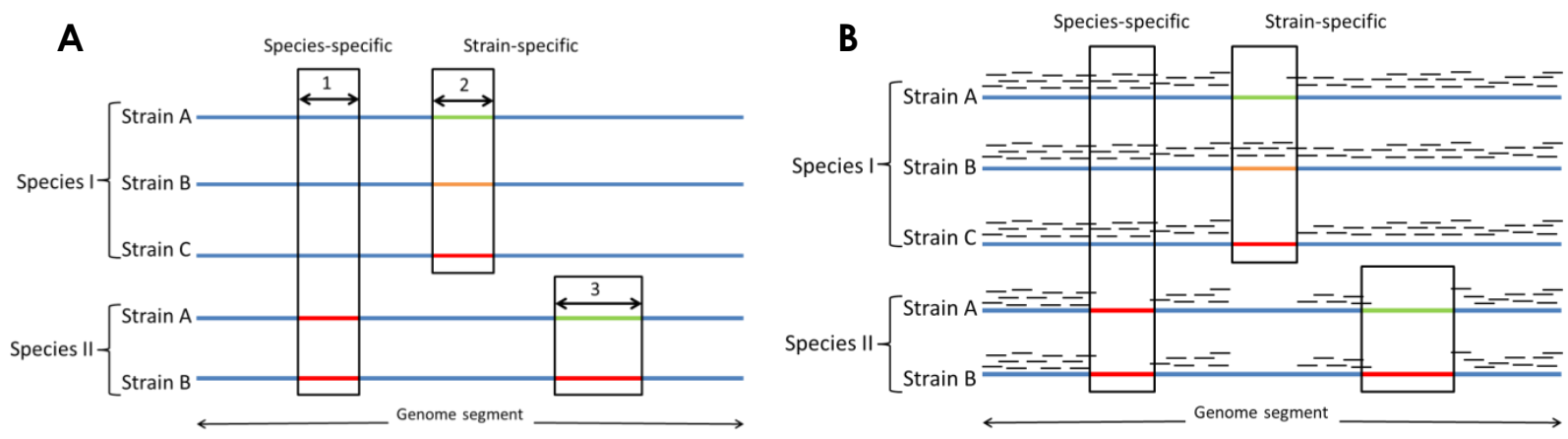

Figure 1. A) For a group of strains belonging to two different species, some regions may be unique to each species (region 1), while other regions may be unique to strains within each species (regions 2 and 3). B) A set of reads are aligned to these genomes, and the ones that align in a species- or strain-specific manner are identified by the combination of genomes to which they align. In this example, Strain B of Species I is the organism identified.

The unique identification of a species or strain is quantified by the proportion of the genome that is determined to be species- or strain-specific (defined as reads that are aligned to regions that are species- or strain-specific). Each species and strain is then assigned a numerical measure of the proportion that is covered by these diagnostic reads, and that proportional measure is compared to the ideal case, where sequences from a single organism (generated in silico) are aligned against the database in an identical manner. After that normalization factor is applied, the resulting score indicates whether the source sample contained any of the organisms in the reference database. 
SIANN: Strain Identification by Alignment to Near Neighbors

The analysis is conducted independently on both the species and the strain level, so that if the true strain is not present in the database, the species of origin will still be identified. While many methods consider the complete taxonomic tree and assign reads to the least common ancestor, SIANN considers only two taxonomic levels: species and strain, throwing out anything that is not unique at one of those levels and thus obviating many of the confounding factors introduced by manually curated taxonomies.

The example shown in Figure $1 \mathrm{~b}$ indicates that species-specific reads are identified as reads that align to one species (Species I, in that case) but not the other. If Species II were not present in the example shown in Figure 1b, a much larger number of reads would be assigned as "species-specific," when in fact those regions are shared with other species. Therefore, the ability of this method to identify strain- and species-specific sequences is a direct function of the inclusion of near neighbors in the reference database. This characteristic is shared among many classification algorithms, but it is of particular note for this method when users have an opportunity to construct their own database.. In order to detect a target species with a high degree of specificity (reducing false positives), it is necessary to include other related species in the reference database. Only by parallel alignment to those near neighbors can the redundant sequences be separated from the species-specific ones. For example, in order to detect Bacillus anthracis in a sample, it would be necessary to include other species of Bacilli in the reference database so that the presence of $B$. cereus or $B$. thuringiensis in a sample does not lead to a false call for B. anthracis.

The nomenclature of genus, species, and strain is potentially problematic because it does not correspond to a consistent degree of evolutionary distance or genomic distinctiveness. The ability to distinguish two organisms by any method using genomic sequence data is proportional to the amount of each genome that is shared or unique. One might assume that any two organisms of the same species will have a relatively predictable amount of shared genomic identity. However, some pairs of organisms from the same species may have less in common than other pairs of organisms from different species or even genera. This ambiguity impacts SIANN in two ways. If two organisms have very little genomic sequence to distinguish them, the sensitivity of SIANN to detect either one will diminish (the rate of false negatives will increase as the likelihood of sequencing unique regions decreases). Conversely, if an organism is extremely dissimilar to the near neighbors selected for the database, the specificity with which SIANN detects that organism will decline (the rate of false positives will increase as the number of related genomes available in the database decreases). For example, if a database contained only E. coli and B.anthracis, a sample containing B. cereus would be misidentified as contraining $B$. anthracis. In the intended use case, a database targeting B. anthracis would contain B. cereus and a number of other near neighbors to prevent that kind of misidentification. It would be convenient to say that 
SIANN: Strain Identification by Alignment to Near Neighbors

an ideal database can be made by calculating the ideal genetic distance between all references and then finding an ideal set of organisms to make up that database, but the behavior of any database will be governed by the particular genomes of the organisms it encounters in the wild. Because not all organisms evolve in the same manner (differences in mutation rate, horizontal gene transfer, recombination, etc), the suitability of a database and method to detect a given organism can only be determined by thorough validation and benchmarking, as well as updating the reference database as needed. Users of SIANN may construct their own custom databases to include newly identified genomes or specific subsets of genomes that best suit their research interests.

Steps to construct a custom database:

1. Select a set of target organisms

2. Gather a set of genome sequences for those target organisms as well as a matched set of near neighbors

3. Using those reference genome sequences as an input, SIANN will:

a. Construct a reference index for alignment

b. Simulate a set of reads from each genome

c. Align each of those simulated read sets to all of the reference genomes

d. Calculate the proportion of each reference genome that is strain- or species-specific

e. [lf two organisms do not have a minimal amount of unique sequences that exceeds the rate of sequencing error, SIANN asks that all but one of those organisms are removed from the database to eliminate redundancy. Note that the user can provide a single representative genome with multiple strain names so that the redundant strain names are not lost.]

The files contained within each SIANN database are a compressed genomic index and a list containing the proportion of each reference genome that was found to be strainor species-specific during database construction.

To run SIANN:

1. Select a pre-made SIANN database and a set of sequences to be analyzed, and

2. SIANN will:

a. Align each of the reads against the reference genomes

b. Calculate the proportion of each reference genome that is strain- or species-specific within those reads

c. Compare that proportion to the simulated ideal case generated during database creation 
bioRxiv preprint doi: https://doi.org/10.1101/001727; this version posted January 10, 2014. The copyright holder for this preprint (which was not certified by peer review) is the author/funder, who has granted bioRxiv a license to display the preprint in perpetuity. It is made available under aCC-BY-NC-ND 4.0 International license.

SIANN: Strain Identification by Alignment to Near Neighbors

d. Calculate the probability that the given results could be generated by random chance

e. Report the normalized proportion and non-parametric statistic of likelihood for each strain and species in the reference database. The normalized proportion of the genome covered by strain- or speciesspecific reads is the primary statistic reported by this tool.

\section{Benchmarking}

The performance of SIANN (version 1.6) was tested in comparison to the following stateof-the-art metagenomic classification programs: LMAT (version 1.2), MetaPhIAn (version 1.7.7), and Kraken (version 0.9.1b). All of the programs in Table 1 were investigated for this effort, and three were chosen based on their ability to run on our high-performance computing cluster with an execution time and memory requirement that would be suitable to a clinical lab. Each program was run on a set of 600 simulated datasets generated by MetaSim (Richter, et al., 2008). Each dataset consisted of 15,000,000 reads (100bp single-ended) with Illumina-simulated error (fourth-degree polynomial) (Korbel, et al., 2009). The 600 datasets were broken into 12 sets of 50 replicates. Each of the 12 sets contained organisms at different levels of abundance as shown in Table 2. Organisms were specifically chosen in pairs so that the ability to distinguish these near neighbors could be determined. The abundances were staggered at 4-fold intervals so that a wide range could be evaluated. All known species of near neighbors for each of

\begin{tabular}{|c|c|c|c|c|c|c|c|c|c|c|c|c|}
\hline Organism & 1 & 2 & 3 & 4 & 5 & 6 & 7 & 8 & 9 & 10 & 11 & 12 \\
\hline $\begin{array}{l}\text { Bacillus } \\
\text { anthracis }\end{array}$ & $0.074 \%$ & $0.30 \%$ & $1.2 \%$ & $4.7 \%$ & $19 \%$ & $76 \%$ & & & & & & \\
\hline $\begin{array}{l}\text { Bacillus } \\
\text { cereus }\end{array}$ & & & & & & & $0.074 \%$ & $0.30 \%$ & $1.2 \%$ & $4.7 \%$ & $19 \%$ & $76 \%$ \\
\hline Hanta virus & & $1.2 \%$ & $4.7 \%$ & $19 \%$ & $76 \%$ & $0.074 \%$ & $0.30 \%$ & & & & & \\
\hline $\begin{array}{l}\text { Rift valley } \\
\text { fever virus }\end{array}$ & $0.30 \%$ & & & & & & & $1.2 \%$ & $4.7 \%$ & $19 \%$ & $76 \%$ & $0.074 \%$ \\
\hline $\begin{array}{l}\text { Clostridium } \\
\text { botulinum }\end{array}$ & & & $19 \%$ & $76 \%$ & $0.074 \%$ & $0.30 \%$ & $1.2 \%$ & $4.7 \%$ & & & & \\
\hline $\begin{array}{l}\text { Clostridium } \\
\text { difficile }\end{array}$ & $1.2 \%$ & $4.7 \%$ & & & & & & & $19 \%$ & $76 \%$ & $0.074 \%$ & $0.30 \%$ \\
\hline $\begin{array}{l}\text { Listeria } \\
\text { fleischmann } \\
\text { eii }\end{array}$ & & & & $0.074 \%$ & $0.30 \%$ & $1.2 \%$ & $4.7 \%$ & $19 \%$ & $76 \%$ & & & \\
\hline $\begin{array}{l}\text { Listeria } \\
\text { monocytog } \\
\text { enes }\end{array}$ & $4.7 \%$ & $19 \%$ & $76 \%$ & & & & & & & $0.074 \%$ & $0.30 \%$ & $1.2 \%$ \\
\hline $\begin{array}{l}\text { Monkeypox } \\
\text { virus }\end{array}$ & & & & & $1.2 \%$ & $4.7 \%$ & $19 \%$ & $76 \%$ & $0.074 \%$ & $0.30 \%$ & & \\
\hline $\begin{array}{l}\text { Vaccinia } \\
\text { virus } \\
\end{array}$ & $19 \%$ & $76 \%$ & $0.074 \%$ & $0.30 \%$ & & & & & & & $1.2 \%$ & $4.7 \%$ \\
\hline $\begin{array}{l}\text { Yersinia } \\
\text { enterocolitic } \\
a\end{array}$ & & & & & & $19 \%$ & $76 \%$ & $0.074 \%$ & $0.30 \%$ & $1.2 \%$ & $4.7 \%$ & \\
\hline $\begin{array}{l}\text { Yersinia } \\
\text { pestis }\end{array}$ & $76 \%$ & $0.074 \%$ & $0.30 \%$ & $1.2 \%$ & $4.7 \%$ & & & & & & & $19 \%$ \\
\hline
\end{tabular}

Table 2. The abundance of each target organism in each set of simulated datasets. Each set is indicated by the number in the top row, and was generated with 50 replicates. 
SIANN: Strain Identification by Alignment to Near Neighbors

the 12 target organisms were included in the reference database used by SIANN for this benchmarking ("Target Pathogen Database") and are shown in Appendix 1.

Each program outputs a distinct measure. Kraken and LMAT both count the reads assigned to each taxon, MetaPhIAn calculates the abundance, and SIANN outputs a measure of the proportion of diagnostic genomic regions present. To put these measures on an even footing, we empirically calculated the false positive rate for each method over all 600 samples, at each possible measure of output. Because each dataset is made up of known organisms, any result can be classified as true or false. Therefore, for any possible result (say, 513 reads classified by LMAT or $1.6 \%$ abundance assigned by MetaPhIAn), one can calculate the proportion of calls with at least the same amount of support that were correct (True Positives/[True Positives+False Positives]), over all of the 600 datasets. That measure is commonly given as Positive Predictive Value (PPV). For each program, the results can be translated from the raw value into a PPV that is based on this empirical measure of error. The key item of interest is the PPV value for the results that we know to be true positives, the defined spike organisms. Another way of describing this approach is to say that the results of each program have been normalized to the false positive error rate that was empirically observed. If another set of samples were generated, the PPV vs. raw value curve (Figure 2) would likely fall differently, but in this case it gives us a means of comparing a diverse set of methods against the same ground truth. If method 1 detects an organism with a higher PPV than method 2 does, it means that method 1 has fewer false positives in the range that it reports true positives, which is the definition of utility in this setting.

For each method, PPV was calculated as a function of raw output value. Briefly, this was done by compiling the output for all 600 samples, labeling each result as false or true based on the sample set that it came from, and then calculating (at each possible value of output) what the proportion of TP/[TP+FP] was for results with at least that level of raw output. Some simplification steps were taken, such as focusing on the specieslevel assignments (for comparison with methods that do not perform strain assignment), and only taking the top hit for each species from each dataset. Custom R and BASH scripts were used for the data compilation and analysis.

\section{Results}

The relationship of raw output value to PPV is shown for each of the four methods in Figure 2. The point at which PPV is very close to 1 (where $95 \%$ of results are true positives) is $\sim 41,000$ reads for Kraken, $\sim 2,800$ reads for LMAT, $\sim 38 \%$ abundance for MetaPhIAn, and 0.21 for SIANN. For SIANN this means that having $38 \%$ of the species-unique genome covered by reads resulted in the vast majority of calls being accurate. 
bioRxiv preprint doi: https://doi.org/10.1101/001727; this version posted January 10,2014 . The copyright holder for this preprint (which was not certified by peer review) is the author/funder, who has granted bioRxiv a license to display the preprint in perpetuity. It is made available under aCC-BY-NC-ND 4.0 International license.

SIANN: Strain Identification by Alignment to Near Neighbors

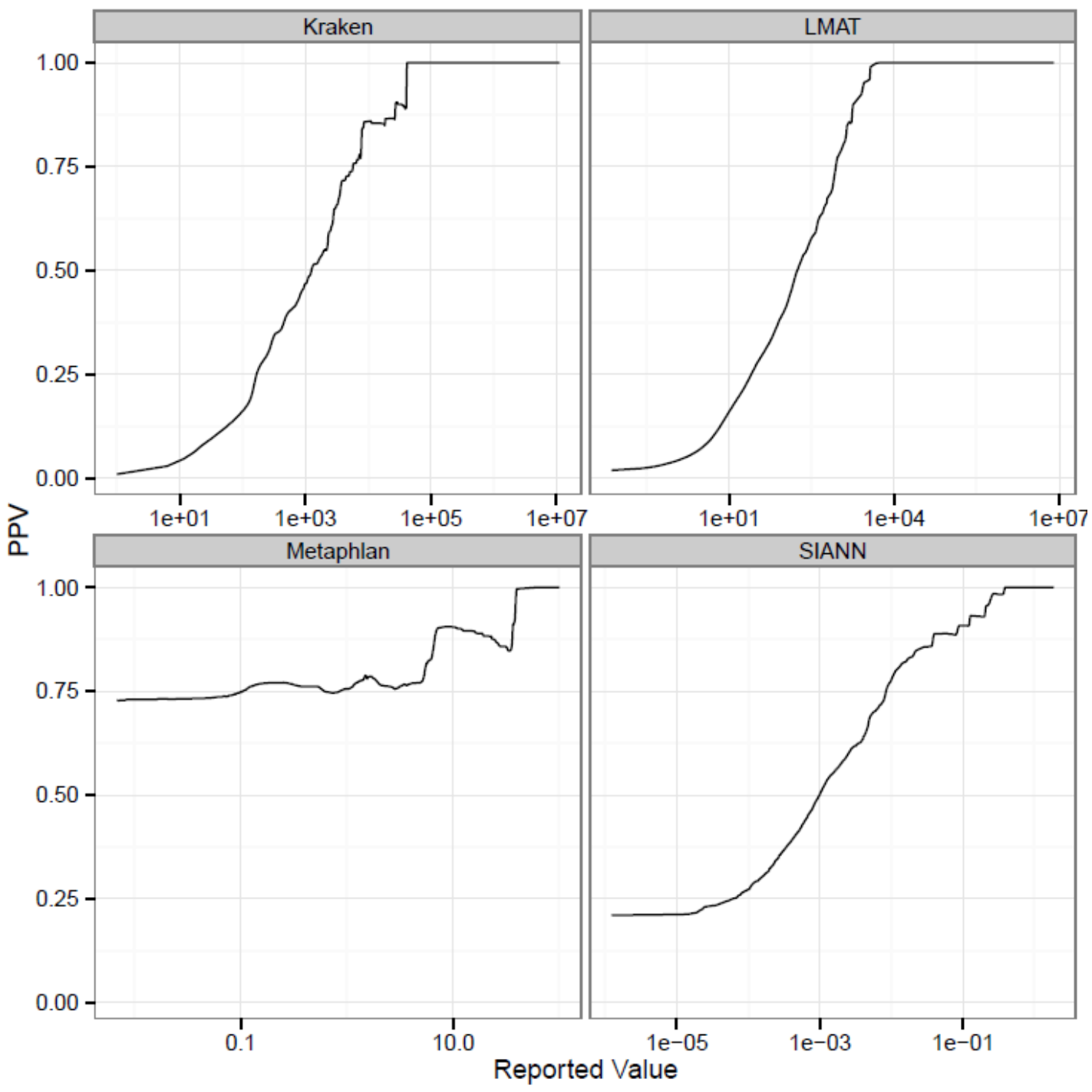

Figure 2. Relationship of reported value for each program (horizontal axis, log scale) to the empirically-determined Positive Predictive Value (PPV), shown on the vertical axis. While the exact values depend on the test data used, the general values at significant cutoff values $(0.8,0.9,0.95 \mathrm{PPV})$ remain relatively constant across different datasets (data not shown). 
SIANN: Strain Identification by Alignment to Near Neighbors

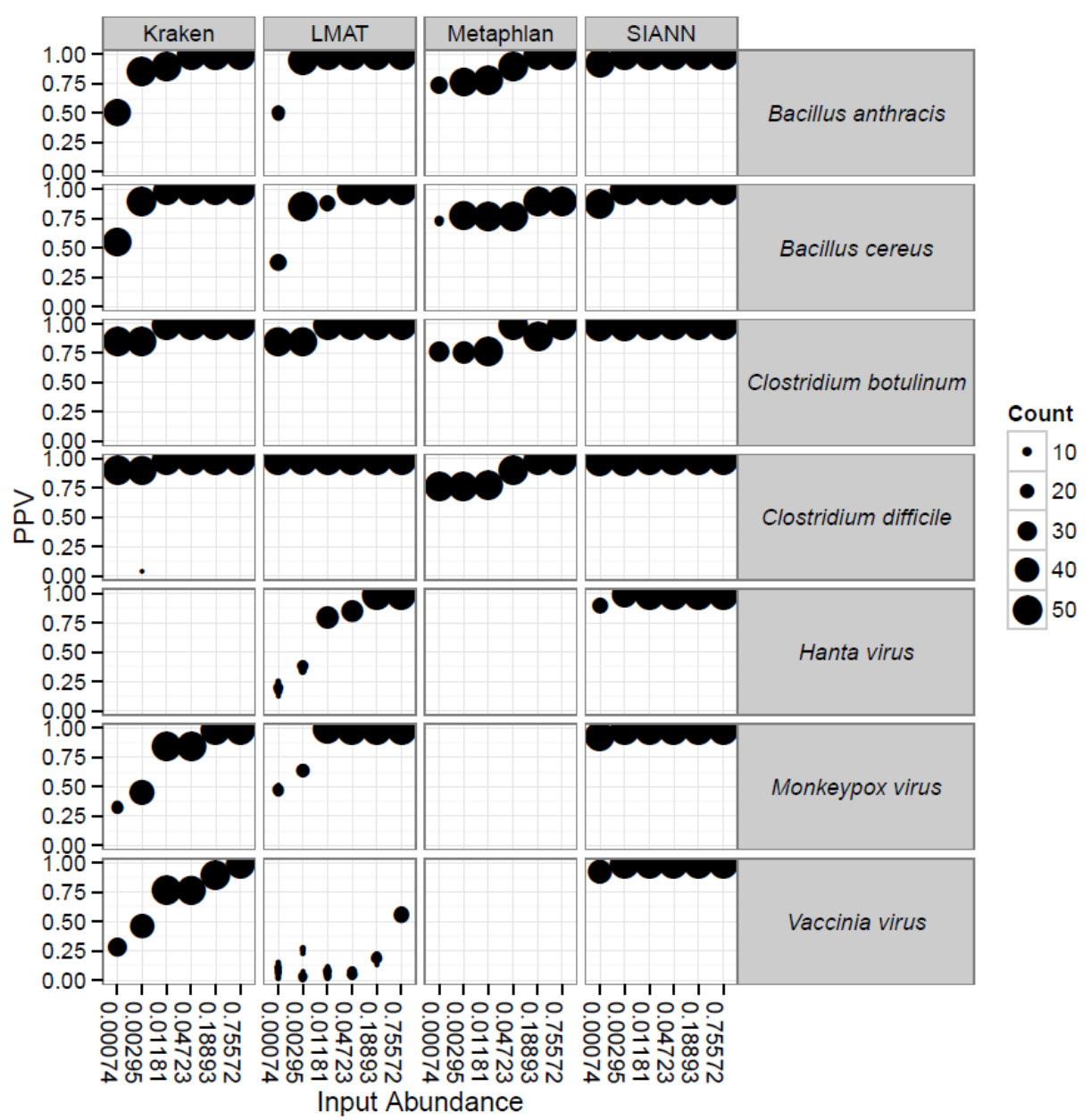

Figure 3. The Positive Predictive Value (PPV, vertical axis) is shown for each organism (boxes on right), at each level of known abundance (horizontal axis, see Table 2), and each program (boxes at top), across a maximum of 50 replicates (indicated by the size of each point). Note that the reference database for MetaPhIAn does not include viruses, and the reference database for Kraken does not include RNA viruses
For

readassignment methods (such as LMAT and Kraken), manual inspection of the results may yield a different understanding of confidence than is presented here, or in any automated analysis. For example, while each read that is assigned by LMAT and Kraken fall above a certain cutoff for speciesspecificity, some individual reads may be much more specific than others. One could identify a read that aligns to a single species of bacteria with $100 \%$ accuracy over its 300bp length, with the next closest match being only $90 \%$ similar. It is extremely unlikely that a 300bp exact match would arise due to random chance, and so the user could say with confidence that the organism of interest is found within the sequence data (not considering contamination, horizontal gene transfer, etc). However, such an approach is not currently implemented in an automated method, and many of the steps needed to make that assertion are performed manually by a domain expert, including alignment to near neighbors and ensuring that the read does not fall within a transposon, plasmid, etc. Therefore, while one could say that a single read is all that is needed to state with high PPV that an organism is present, the amount of reads assigned in an automated manner needed to achieve that level of PPV will number in the thousands (Fig 2). 
SIANN: Strain Identification by Alignment to Near Neighbors

The next phase of benchmarking was to determine how many raw input reads were needed to achieve the threshold for high PPV. To demonstrate this we plotted the known abundance of each spike organism against the PPV value generated by each method (Figure 3). Each point (an organism at a known level of abundance) is comprised of a maximum of 50 replicates, where the diameter of each point increases with an increasing number of replicates. For demonstration purposes we are showing two pairs of bacteria and three viruses. Recall that for each of the pairs of bacteria (and the two poxviruses) any sample containing one did not contain the other (as shown in Table 1). The empty boxes result from the organisms not being called at any abundance. For MetaPhIAn, that is a result of no viruses being included in the version of the reference database available for this analysis. Kraken assigned no reads to Hanta virus because viral RNA genomes were not included in this version of the reference database (personal communication with D. Wood). This emphasizes the point that a) the ability to create custom databases targeting organisms of interest can be valuable, and b) the performance of any method must be benchmarked against each potential target of interest.

All methods were able identify the bulk of organisms in their databases at high abundances $(75 \%$ and $18 \%$, Figure 3 ), however performance varied considerably at lower abundances and depended on the particular organism and method used. SIANN detected each organism at high confidence, even at levels as low as $0.3 \%$ and $0.07 \%$ of the total.

\section{Discussion}

The process of detecting trace amounts of a specific organism in a complex mixture of DNA is challenging enough for an expert, but that pales in comparison to the difficulty of accomplishing the same certainty of detection in an automated manner. The results presented here show that SIANN rapidly detects the presence of a given set of organisms with a high degree of specificity and sensitivity. For example, at the $95 \%$ confidence (PPV) cutoff of 0.2, SIANN reliably detects all of the organisms tested here at as low as $0.3 \%$ abundance. This strong performance is likely due to the fact that SIANN is able to use a method (read alignment to whole genomes) that would be far too computationally costly if it were applied to the entire collection of known genomes. By focusing on a set of (customizable) target organisms and their near neighbors, SIANN can operate quickly and with low computational requirements while delivering highly accurate results.

SIANN is available on Illumina's Basespace (www.basespace.illumina.com) as a NativeApp, with the database tested here (Appendix 1), as well as a database made from the $\mathrm{NCBl}$ representative set of prokaryotic genomes (ftp://ftp.ncbi.nlm.nih.gov/genomes/genome reports/) (Appendix 2) and the complete set of NCBI viral genomes (ftp://ftp.ncbi.nlm.nih.gov/refseg/release/viral/) (Appendix 3). 
SIANN: Strain Identification by Alignment to Near Neighbors

BaseSpace was chosen as an appropriate release platform because while the entire set of software and dependencies can be deployed by the user from within a graphical user interface, the actual computation takes place in a controlled 'cloud' environment. Such a distribution strategy obviates the need to satisfy the multiple software or OS dependencies that often arises with academic computational methods. Results for SIANN are compiled into a report format, showing both the organisms that surpass $95 \%$ confidence, as well as the closest strain match for each species. The default view masks the raw data output, so that the results are human-readable and do not present extraneous information. While the code for execution and databaseconstruction on a users system is available from Signature Science, LLC, additional databases on the Basespace platform can be made available upon request.

There is a neverending list of questions that one could ask of metagenomic sequencing data generated from important samples. Instead of answering them all, we demonstrate a technique with a very narrow focus that is able to report with a high degree of confidence whether a given set of organisms is present in a sample. These results are presented to the user in a comprehensible format, and accessible on a commonly-used web platform. The world of bioinformatics will continue to progress and develop more sophisticated tools for metagenomic analysis, and we hope that the utility of SIANN will convince others to package and benchmark their tools in a way that they can be used with confidence by the larger public, as well as the research community. 
SIANN: Strain Identification by Alignment to Near Neighbors

\section{References}

Ames SK, Hysom DA, Gardner SN, Lloyd GS, Gokhale MB, and Allen JE (2013). Scalable metagenomic taxonomy classification using a reference genome database. Bioinformatics, 29(18):2253-60. doi: 10.1093/bioinformatics/btt389.

Bazinet $\mathrm{AL}$ \& Cummings MP (2012). A comparative evaluation of sequence classification programs. BMC Bioinformatics. 13: 92. doi: 10.1 186/1471-2105-13-92

Berendzen J, Bruno WJ, Cohn JD, Hengartner NW, Kuske CR, MCMahon BH, Wolinsky MA and Xie G (2012). Rapid phylogenetic and functional classification of short genomic fragments with signature peptides. BMC Research Notes, 5:460 doi:10.1 186/1756-0500-5460

Brady A and Salzberg SL (2009). Phymm and PhymmBL: metagenomic phylogenetic classification with interpolated Markov models. Nature Methods, 6(9):673-6. doi: 10.1038/nmeth.1358.

Huson DH, Mitra S, Weber N, Ruscheweyh H, and Schuster SC (2011). Integrative analysis of environmental sequences using MEGAN4. Genome Research, 21:1552-1560.

Korbel JO, Abyzov A, Mu XJ, Carriero N, Cayting P, Zhang Z, Snyder M and Gerstein MB (2009). PEMer: a computational framework with simulation-based error models for inferring genomic structural variants from massive paired-end sequencing data. Genome Biology, 10:R23 doi:10.1186/gb-2009-10-2-r23

Langmead B, Salzberg S. Fast gapped-read alignment with Bowtie 2. Nature Methods. 2012, 9:357-359.

Liu B, Gibbons T, Ghodsi M, Treangen T, and Pop M (2011). Accurate and fast estimation of taxonomic profiles from metagenomic shotgun sequences. BMC Genomics, 12(Suppl 2):S4

Richter DC, Ott F, Auch AF, Schmid R, Huson DH (2008). MetaSim: a sequencing simulator for genomics and metagenomics.PLoS One, 3(10):e3373. doi: 10.1371/journal.pone.0003373

Schloissnig S, Arumugam M, Sunagawa S, Mitreva M, Tap J, Zhu A, Waller A, Mende DR, Kultima JR, Martin J, Kota K, Sunyaev SR, Weinstock GM, Bork P (2013). Genomic variation landscape of the human gut microbiome. Nature, 493(7430):45-50. doi: 10.1038/nature 11711

Segata N, Boernigen D, Tickle TL, Morgan XC, Garrett WS, Huttenhower C (2013). Computational meta'omics for microbial community studies. Molecular Systems Biology, 14(9):666. doi: 10.1038/msb.2013.22 
SIANN: Strain Identification by Alignment to Near Neighbors

Segata N, Waldron L, Ballarini A, Narasimhan V, Jousson O, and Huttenhower C (2012). Metagenomic microbial community profiling using unique clade-specific marker genes. Nature Methods, 9(8):811-4. doi: 10.1038/nmeth.2066.

Sunagawa S, Mende DR, Zeller G, Izquierdo-Carrasco F, Berger SA, Kultima JR, Coelho LP, Arumugam M, Tap J, Nielsen HB, Rasmussen S, Brunak S, Pedersen O, Guarner F, de Vos WM, Wang J, Li J, Doré J, Ehrlich SD, Stamatakis A \& Bork P (2013). Metagenomic species profiling using universal phylogenetic marker genes. Nature Methods, 10, $1196-$ 1199 (2013) doi:10.1038/nmeth.2693

Wood DE and Salzberg SL. Ultrafast metagenomic sequence classification using exact alignments. In submission.

Wu GD, Chen J, Hoffmann C, Bittinger K, Chen YY, Keilbaugh SA, Bewtra M, Knights D, Walters WA, Knight R, Sinha R, Gilroy E, Gupta K, Baldassano R, Nessel L, Li H, Bushman FD, Lewis JD (2011). Linking long-term dietary patterns with gut microbial enterotypes. Science. 334(6052):105-8. doi: 10.1126/science.1208344. 
bioRxiv preprint doi: https://doi.org/10.1101/001727; this version posted January 10,2014 . The copyright holder for this preprint (which was not certified by peer review) is the author/funder, who has granted bioRxiv a license to display the preprint in perpetuity. It is made available under aCC-BY-NC-ND 4.0 International license.

SIANN: Strain Identification by Alignment to Near Neighbors

\section{Appendices}

\section{Appendix 1: Target Pathogen Database}

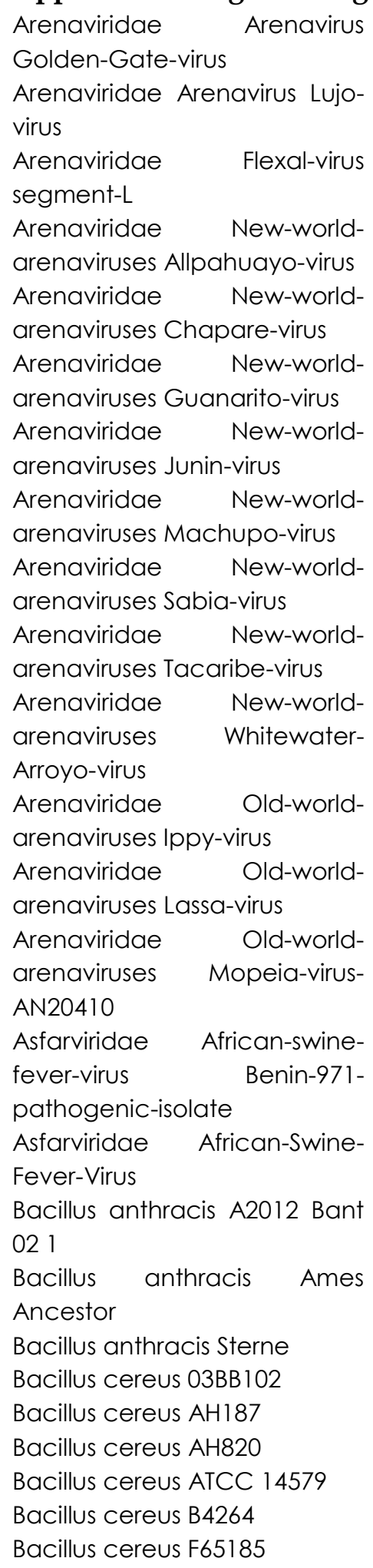

Bacillus cytotoxicus NVH 39198

Bacillus mycoides DSM 2048

Bacillus mycoides Rock 1-4

Bacillus thuringiensis $\mathrm{BMB} 171$

Bacillus thuringiensis $\mathrm{B}+407$

Bacillus thuringiensis HD-771

Bacillus thuringiensis serovar chinensis CT-43

Bacillus thuringiensis serovar konkukian 97-27

Brucella abortus A13334

Brucella ceti B1 94

Brucella ceti M13 $05 \quad 1$

supercontl 22

Brucella melitensis ATCC

23457

Brucella melitensis bv 1 str $16 \mathrm{M}$

Brucella ovis ATCC 25840

Brucella suis 1330

Brucella suis ATCC 23445

Bunyaviridae Akabane-virus

segment-M

Bunyaviridae Hantavirus

Andes-virus

Bunyaviridae Hantavirus

Dobrava-Belgrade-virus-strain-

DOBV-Ano-Poroia-Af19-1999

Bunyaviridae Hantavirus

Hantaan-virus

Bunyaviridae Hantavirus

Puumala-virus

Bunyaviridae Hantavirus

clone-1

Bunyaviridae Hantavirus Sin-

Nombre-virus

Bunyaviridae Hantavirus

Thottapalayam-virus

Bunyaviridae Hantavirus Tulavirus

Bunyaviridae Nairovirus

Crimean-Congo-

hemorrhagic-fever-virus

Bunyaviridae Nairovirus

Dugbe-virus
Bunyaviridae Phlebovirus RiftValley-fever-virus

Burkholderia cenocepacia HI2424

Burkholderia cenocepacia

J2315

Burkholderia cenocepacia

MCO-3

Burkholderia cepacia GG4

Burkholderia gladioli BSR3

Burkholderia glumae BGR 1

Burkholderia

mallei

2002721280

Burkholderia mallei ATCC

10399

Burkholderia mallei NCTC 10247

Burkholderia mallei SAVPI

Burkholderia multivorans

ATCC 17616

Burkholderia oklahomensis

C6786

Burkholderia oklahomensis

EO147

Burkholderia pseudomallei

1026b

Burkholderia pseudomallei

$1106 a$

Burkholderia pseudomallei

1710b

Burkholderia pseudomallei

668

Burkholderia pseudomallei

BPC006

Burkholderia pseudomallei

K96243

Burkholderia pyrrocinia $\mathrm{CH}-67$

Burkholderia thailandensis

ATCC 700388

Burkholderia thailandensis

E264

Burkholderia thailandensis

MSMB121

Campylobacter coli JV20

Campylobacter fetus subsp fetus $82-40$

Campylobacter jejuni RM1221 
bioRxiv preprint doi: https://doi.org/10.1101/001727; this version posted January 10,2014 . The copyright holder for this preprint (which was not certified by peer review) is the author/funder, who has granted bioRxiv a license to display the preprint in perpetuity. It is made available under aCC-BY-NC-ND 4.0 International license.

SIANN: Strain Identification by Alignment to Near Neighbors

Campylobacter jejuni subsp doylei 26997

Campylobacter jejuni subsp jejuni 81-176

Campylobacter jejuni subsp jejuni NCTC 11168 ATCC 700819

Campylobacter upsaliensis JV21

Clostridium acetobutylicum

DSM 1731

Clostridium botulinum A str

ATCC 3502

Clostridium botulinum

BKT015925

Clostridium botulinum B str

Eklund 17B

Clostridium botulinum E3 str

Alaska E43

Clostridium botulinum $F$ str 230613

Clostridium botulinum $\mathrm{H} 04402$

065

Clostridium difficile 2007855

Clostridium difficile 630

Clostridium difficile BII

Clostridium difficile B19

Clostridium perfringens ATCC 13124

Clostridium perfringens SM101

Clostridium perfringens str 13

Clostridium symbiosum WAL-

14163

Clostridium symbiosum WAL-

14673

Clostridium tetani E88

Clostridium thermocellum

ATCC 27405

Clostridium thermocellum

DSM 1313

Clostridium tunisiense TJ C661

Clostridium ultunense Esp

Coccidioides immitis H5384

Coccidioides immitis RMSCC 2394

Coccidioides immitis RS

Coccidioides posadasii $\mathrm{C} 735$

delta SOWgp

Coccidioides posadasii CPA 0001
Coccidioides posadasii CPA

0020

Coronaviridae

Alphacoronavirus

Bat-

coronavirus-HKU2

Coronaviridae

Alphacoronavirus Feline-

infectious-peritonitis-virus

Coronaviridae

Alphacoronavirus Human-

coronavirus-229E

Coronaviridae

Alphacoronavirus TGEV-

Purdue-P115

Coronaviridae Bafinivirus

White-bream-virus

Coronaviridae

Betacoronavirus Bovine-

coronavirus

Coronaviridae

Betacoronavirus Murine-

hepatitis-virus-strain-A59

Coronaviridae

Betacoronavirus Murine-

hepatitis-virus-strain-JHM

Coronaviridae

Betacoronavirus

SARS-

coronavirus

Coronaviridae Coronavirinae

Munia-coronavirus-HKU13-

3514

Coronaviridae

Gammacoronavirus Avian-

infectious-bronchitis-virus

Coronaviridae

Gammacoronavirus Turkey-

coronavirus

Coronaviridae Torovirus

Breda-virus

Coronaviridae unclassified-

coronaviruses Bat-

coronavirus-BM48-31-BGR-

2008

Coronaviridae unclassified-

coronaviruses Bovine-

respiratory-coronavirus-AH 187

Coronaviridae unclassified-

coronaviruses Human-enteric-

coronavirus-strain-4408

Coxiella burnetii CbuG Q212
Coxiella burnetii Dugway

5J108 111

Coxiella burnetii RSA 493

Diplorickettsia massiliensis $20 B$

CS 1

Ehrlichia canis str Jake

Ehrlichia chaffeensis str

Arkansas

Ehrlichia chaffeensis str

Sapulpa ctg90

Ehrlichia ruminantium str

Gardel

Ehrlichia ruminantium str

Welgevonden

Escherichia coli APEC O1

Escherichia coli BL21 DE3

Escherichia coli B str REL606

Escherichia coli ETEC H10407

Escherichia coli O104H4 str

2011 C-3493

Escherichia coli O157H7 str

EC4115

Escherichia coli O157H7 str

Sakai

Escherichia coli O7K 1 str CE10

Escherichia coli $\mathrm{O} 83 \mathrm{HI}$ str

NRG 857C

Escherichia coli str K-12 substr

MG1655

Filoviridae Ebolavirus

Bundibugyo-ebolavirus

Filoviridae Ebolavirus Cote-

dlvoire-ebolavirus

Filoviridae Ebolavirus Ebola-

virus-Mayinga-Zaire

Filoviridae Ebolavirus Reston-

ebolavirus

Filoviridae Ebolavirus Sudan-

ebolavirus

Filoviridae Marburgvirus LakeVictoria-marburgvirus-Musoke

Flaviviridae Alkhurma-virus

Flaviviridae Classical-swine-

fever-virus

Flaviviridae Dengue-virus 1

Flaviviridae Dengue-virus 2

Flaviviridae Dengue-virus 3

Flaviviridae Dengue-virus 4

Flaviviridae

Japanese-

encephalitis-virus genome

Flaviviridae Karshi-virus 
bioRxiv preprint doi: https://doi.org/10.1101/001727; this version posted January 10,2014 . The copyright holder for this preprint (which was not certified by peer review) is the author/funder, who has granted bioRxiv a license to display the preprint in perpetuity. It is made available under aCC-BY-NC-ND 4.0 International license.

SIANN: Strain Identification by Alignment to Near Neighbors

Flaviviridae Langat-virus

Flaviviridae Louping-ill-virus

Flaviviridae Murray-Valley-

encephalitis-virus

Flaviviridae Omsk-

hemorrhagic-fever-virus

Flaviviridae Powassan-virus

Flaviviridae St-Louis-

encephalitis-virus

Flaviviridae Tick-borne-

encephalitis-virus

Flaviviridae Usutu-virus

Flaviviridae West-Nile-virus

Flaviviridae Yellow-fever-virus

Francisella cf novicida Fxl

Francisella noatunensis subsp

orientalis str Toba 04

Francisella novicida U1 12

Francisella philomiragia subsp

philomiragia ATCC 25015

Francisella philomiragia subsp

philomiragia ATCC 25017

Francisella tularensis subsp

holarctica F92

Francisella tularensis subsp

mediasiatica FSC 147

Francisella tularensis subsp

tularensis FSC 198

Herpesviridae Alcelaphine-

herpesvirus 1

Herpesviridae Macacine-

herpesvirus 1

Listeria fleischmannii LU2006-1

c88

Listeria innocua Clip 1262

Listeria innocua FSL J1-023

Listeria ivanovii FSL F6-596

Listeria ivanovii subsp ivanovii

PAM 55

Listeria marthii FSL S4-120

Listeria monocytogenes

07PF0776

Listeria monocytogenes 08-

5578

Listeria monocytogenes

10403S

Listeria monocyłogenes ATCC 19117

Listeria monocytogenes

Finland 1998
Listeria monocytogenes FSL

R2-561

Listeria monocytogenes La111

Listeria seeligeri FSL N1-067

Listeria seeligeri serovar $12 \mathrm{~b}$ str

SLCC3954

Listeria welshimeri serovar 6b

str SLCC5334

Paramyxoviridae Avulavirus

Newcastle-disease-virus-B 1

Paramyxoviridae Henipavirus

Hendra-virus

Paramyxoviridae Henipavirus

Nipah-virus

Paramyxoviridae Menangle-

virus

Paramyxoviridae Morbillivirus

Measles-virus

Paramyxoviridae Peste-des-

petits-ruminants-virus

Paramyxoviridae Respirovirus

Human-parainfluenza-virus-1

Paramyxoviridae Respirovirus

Human-parainfluenza-virus-3

Paramyxoviridae Respirovirus

Sendai-virus

Paramyxoviridae Rinderpest-

virus strain-Kabete-O

Paramyxoviridae Rubulavirus

Human-parainfluenza-virus-2

Paramyxoviridae Rubulavirus

Human-parainfluenza-virus-4a

Paramyxoviridae Rubulavirus

Mumps-virus

Picornaviridae Foot-and-

mouth-disease-virus -type-O

Picornaviridae Swine-

vesicular-disease-virus strain-

HK70

Picornaviridae Swine-

vesicular-disease-virus strain-

NET192

Poxviridae Avipoxvirus

Fowlpox-virus

Poxviridae Crocodylidpoxvirus

Nile-crocodilepox-virus

Poxviridae Goatpox-virus

Pellor

Poxviridae Leporipoxvirus

Myxoma-virus
Poxviridae Lumpy-skin-

disease-virus NI-2490

Poxviridae Molluscipoxvirus

Molluscum-contagiosum-virus-

subtype-1

Poxviridae Orthopoxvirus

Camelpox-virus

Poxviridae Orthopoxvirus

Cowpox-virus

Poxviridae Orthopoxvirus

Ectromelia-virus

Poxviridae Orthopoxvirus

Monkeypox-virus-Zaire-96-I-16

Poxviridae Orthopoxvirus

Taterapox-virus

Poxviridae Orthopoxvirus

Vaccinia-virus

Poxviridae Orthopoxvirus

Variola-virus

Poxviridae Sheeppox-virus

17077-99

Poxviridae

Suipoxvirus

Swinepox-virus

Puccinia graminis $f \mathrm{sp}$ tritici

CRL 75-36-700-3

Ralstonia pickettii 12D

Ralstonia pickettii 12J

Ralstonia solanacearum

CFBP2957

Ralstonia solanacearum

CMR 15

Ralstonia solanacearum

GMI1000

Rathayibacter toxicus DSM

7488

Reoviridae African-

horsesickness-virus segment-

10

Rhabdoviridae Vesicular-

stomatitis-Indiana-virus

Rhabdoviridae Vesicular-

stomatitis-virus strain-

NJ2075212NM

Rickettsia bellii OSU 85-389

Rickettsia conorii str Malish 7

Rickettsia prowazekii str Breinl

Rickettsia prowazekii str

RpGvF24

Rickettsia rickettsii str Arizona

Rickettsia typhi str B9991CWPP

Rickettsiella grylli gcontig 634 
bioRxiv preprint doi: https://doi.org/10.1101/001727; this version posted January 10,2014 . The copyright holder for this preprint (which was not certified by peer review) is the author/funder, who has granted bioRxiv a license to display the preprint in perpetuity. It is made available under aCC-BY-NC-ND 4.0 International license.

SIANN: Strain Identification by Alignment to Near Neighbors

Salmonella bongori N268-08

Salmonella bongori NCTC 12419

Salmonella enterica subsp arizonae serovar 62z4z23- str RSK2980

Salmonella enterica subsp enterica serovar Dublin str CT 02021853

Salmonella enterica subsp enterica serovar Newport str SL254

Salmonella enterica subsp enterica serovar Paratyphi A str ATCC 9150

Salmonella enterica subsp enterica serovar Typhimurium str LT2

Salmonella enterica subsp enterica serovar Typhi str Ty2

Shigella boydii CDC 3083-94

Shigella boydii Sb227

Shigella dysenteriae Sd197

Shigella flexneri 2002017

Shigella flexneri 2a str 2457T

Shigella flexneri 2 a str 301

Shigella flexneri 5 str 8401

Shigella sonnei $53 G$

Shigella sonnei Ss046

Staphylococcus arlettae

CVD059 SARL C230

Staphylococcus aureus 0402981

Staphylococcus aureus

O8BA02176

Staphylococcus aureus subsp aureus N315

Staphylococcus aureus subsp aureus NCTC 8325

Staphylococcus aureus subsp aureus TW20

Staphylococcus capitis QN1 Contig63
Staphylococcus capitis SK 14

Staphylococcus caprae C87

Staphylococcus carnosus

subsp carnosus TM300

Staphylococcus epidermidis

ATCC 12228

Staphylococcus epidermidis

RP62A

Staphylococcus equorum

subsp equorum Mu2

Staphylococcus haemolyticus

JCSC 1435

Staphylococcus hominis

SK 119

Staphylococcus hominis

subsp hominis C80

Staphylococcus lugdunensis

HKU09-01

Staphylococcus lugdunensis

N920143

Togaviridae Alphavirus

Barmah-Forest-virus

Togaviridae Chikungunya-

virus

Togaviridae EEEV-complex

Eastern-equine-encephalitis-

virus

Togaviridae Rubivirus Rubellavirus

Togaviridae SFV-complex Onyong-nyong-virus

Togaviridae Venezuelanequine-encephalitis-virus

Togaviridae WEEV-complex

Sindbis-virus

Togaviridae Western-equineencephalomyelitis-virus

Xanthomonas albilineans GPE PC73

Xanthomonas axonopodis

Xac29-1

Xanthomonas oryzae pv

oryzae KACC 10331
Xanthomonas oryzae pv

oryzae MAFF 311018

Xanthomonas oryzae pv

oryzae PXO99A

Xanthomonas vasicola pv

vasculorum NCPPB 1326 scf

97674580

Yersinia aldovae ATCC 35236

Yersinia bercovieri ATCC

43970

Yersinia enterocolitica IP 10393

Yersinia enterocolitica IP2222

Yersinia enterocolitica subsp

enterocolitica 8081

Yersinia enterocolitica subsp

palearctica $1055 R$

Yersinia frederiksenii ATCC

33641

Yersinia intermedia ATCC

29909

Yersinia kristensenii ATCC

33638

Yersinia mollaretii ATCC 43969

Yersinia pestis Al 122

Yersinia pestis Antiqua

Yersinia pestis KIM 10

Yersinia pestis Pestoides $\mathrm{F}$

Yersinia pseudotuberculosis IP

31758

Yersinia pseudotuberculosis IP 32953

Yersinia pseudotuberculosis

PB1

Yersinia pseudotuberculosis

YPIII

Yersinia rohdei ATCC 43380

Yersinia ruckeri ATCC 29473 
bioRxiv preprint doi: https://doi.org/10.1101/001727; this version posted January 10,2014 . The copyright holder for this preprint (which was not certified by peer review) is the author/funder, who has granted bioRxiv a license to display the preprint in perpetuity. It is made available under aCC-BY-NC-ND 4.0 International license.

SIANN: Strain Identification by Alignment to Near Neighbors

\section{Appendix 2: Viral Database}

\author{
Abaca bunchy top virus DNA-
}

C

Abaca bunchy top virus DNA-

M

Abaca bunchy top virus DNA-

$\mathrm{N}$

Abaca bunchy top virus DNA-

$\mathrm{R}$

Abaca bunchy top virus DNA$S$

Abaca bunchy top virus segment 2

Abalone shriveling syndromeassociated virus

Abutilon Brazil virus DNA A

Abutilon Brazil virus DNA B

Abutilon mosaic virus DNA A

Abutilon mosaic virus DNA B

Acanthocystis turfacea

Chlorella virus 1

Acheta domesticus

densovirus

Acholeplasma phage $\mathrm{L} 2$

Acholeplasma phage MV-L1

Acidianus bottle-shaped virus

Acidianus filamentous virus 1

Acidianus filamentous virus 2

Acidianus filamentous virus 3

Acidianus filamentous virus 6

Acidianus filamentous virus 7

Acidianus filamentous virus 8

Acidianus filamentous virus 9

Acidianus rod-shaped virus 1

Acidianus spindle-shaped

virus 1

Acidianus two-tailed virus

Actinomyces phage Av-1

Actinoplanes phage phiAsp2

Acyrthosiphon pisum

bacteriophage APSE-1

Adeno-associated virus-1

Adeno-associated virus-2

Adeno-associated virus-3

Adeno-associated virus-4

Adeno-associated virus 5

Adeno-associated virus-7

Adeno-associated virus-8

Adoxophyes honmai NPV
Adoxophyes

granulovirus

Adoxophyes

orana

nucleopolyhedrovirus

Aedes aegypti densovirus

Aedes albopictus densovirus

Aedes taeniorhynchus

iridescent virus

Aeromonas phage 25

Aeromonas phage 31

Aeromonas phage 44RR2.8t

Aeromonas phage Aeh 1

Aeromonas phage phiO18P

african cassava mosaic virus

DNA A

african cassava mosaic virus

DNA B

African green monkey

polyomavirus

African swine fever virus

Ageratum enation virus

Ageratum leaf Cameroon

betasatellite

Ageratum leaf curl virus-G52

Ageratum yellow vein China virus-associated DNA beta

Ageratum yellow vein

Chinavirus

Ageratum yellow vein Hualian

virus-TaiwanHsinchutom2003

DNA A

Ageratum yellow vein Sri

Lanka virus segment $A$

Ageratum yellow vein Taiwan

virus

Ageratum yellow vein

virusassociated DNA beta

Ageratum yellow veinvirus

Agrotis ipsilon multiple

nucleopolyhedrovirus

Agrotis segetum granulovirus

Agrotis segetum

nucleopolyhedrovirus

Alcelaphine herpesvirus 1

Aleutian mink disease virus

Allamanda leaf curl virus

DNA-A

Alternanthera yellow vein virus DNA-A
Alternanthera yellow vein

virus satellite DNA beta

Ambystoma tigrinum virus

Amsacta

moorei

entomopoxvirus L

Anguillid herpesvirus 1

Anopheles gambiae

densonucleosis virus

Antheraea pernyi

nucleopolyhedrovirus

Anticarsia gemmatalis

nucleopolyhedrovirus

Archaeal BJI virus

Ateline herpesvirus 3

Autographa californica

nucleopolyhedrovirus

Avian adeno-associated virus

ATCC VR-865

Avian adeno-associated virus strain DA-1

Avian endogenous retrovirus

EAV-HP

Azospirillum phage $\mathrm{Cd}$

Bacillus phage 0305phi8-36

Bacillus phage AP50

Bacillus phage B103

Bacillus phage Bam35c

Bacillus phage BCJAlC

Bacillus phage Cherry

Bacillus phage Fah

Bacillus phage GA-1

Bacillus phage Gamma

Bacillus phage GIL16C

Bacillus phage IEBH

Bacillus phage phi105

Bacillus phage phi29

Bacillus phage SPBC2

Bacillus phage SPO1

Bacillus phage SPP1

Bacillus phage TP21-L

Bacillus phage WBeta

Bacillus prophage phBC6A51

Bacillus prophage phBC6A52

Bacillus virus 1

Bacteriophage Aaphi23

Bacteriophage APSE-2

Bacteriophage PSA

Bacteriophage RB32

Bacteroides phage B40-8 
bioRxiv preprint doi: https://doi.org/10.1101/001727; this version posted January 10,2014 . The copyright holder for this preprint (which was not certified by peer review) is the author/funder, who has granted bioRxiv a license to display the preprint in perpetuity. It is made available under aCC-BY-NC-ND 4.0 International license.

SIANN: Strain Identification by Alignment to Near Neighbors

Banana bunchy top virus DNA

C Banana bunchy top virus DNA M

Banana bunchy top virus DNA $\mathrm{N}$

Banana bunchy top virus DNA $\mathrm{R}$

Banana bunchy top virus DNA $S$

Banana bunchy top virus DNA U3

Banana streak GF virus

Banana streak Mysore virus

Banana streak $O L$ virus

Banana streak virus genome

Banana streak virus strain

Acuminata Vietnam

Bandicoot papillomatosis

carcinomatosis virus type 1

Bandicoot papillomatosis

carcinomatosis virus type 2

Bat adeno-associated virus YNM

Bdellovibrio phage phiMH2K

Beak and feather disease virus

Bean calico mosaic virus DNA

A

Bean calico mosaic virus DNA

B

Bean dwarf mosaic virus DNA

A

Bean dwarf mosaic virus DNA B

Bean golden mosaic virus

DNA A

Bean golden mosaic virus

DNA B

Bean golden yellow mosaic virus DNA A

Bean golden yellow mosaic virus DNA B

Bean yellow dwarf virus putative genes $\mathrm{V} 1$

Beet curly top Iran virus-K

Beet curly top virus-California Logan

Beet mild curly top virusWorland4

Beet severe curly top virus-Cfh
Begomovirus-associated DNA

II

Begomovirus-associated

DNA-III

Bettongia penicillata

papillomavirus 1

Bhendi yellow vein

Bhubhaneswar virus DNA-A

Bhendi yellow vein Delhi virus

2004New Delhi DNA-A

Bhendi yellow vein mosaic virus-associated DNA beta

Bhendi yellow vein mosaic

Virus

Bitter gourd leaf curl disease-

associated DNA beta

BK polyomavirus

Blainvillea yellow spot virus

DNA-A

Blainvillea yellow spot virus

DNA-B

Blattella germanica

densovirus

Blueberry red ringspot virus

Bocavirus gorillaGBoV12009

Bombyx mandarina

nucleopolyhedrovirus

Bombyx mori densovirus 5

Bombyx mori NPV

Bordetella phage BIP-1

Bordetella phage BMP-1

Bordetella phage BPP-1

Bougainvillea spectabilis

chlorotic vein-banding virus

Bovine adeno-associated

virus

Bovine adenovirus $A$

Bovine adenovirus $B$

Bovine adenovirus $D$

Bovine ephemeral fever virus

Bovine foamy virus

Bovine herpesvirus 1

Bovine herpesvirus 4 long

unique region

Bovine herpesvirus 5

Bovine papillomavirus- 1

Bovine papillomavirus 3

Bovine papular stomatitis virus

Bovine parvovirus 2

Bovine Parvovirus

Bovine polyomavirus
Burkholderia ambifaria phage

BcepF1

Burkholderia phage Bcep 176

Burkholderia phage Bcep 1

Burkholderia phage Bcep22

Burkholderia phage Bcep43

Burkholderia phage Bcep781

Burkholderia phage BcepB $1 A$

Burkholderia phage BcepC6B

Burkholderia phage

BcepGomr

Burkholderia phage BceplL02

Burkholderia phage BcepMu

Burkholderia phage

BcepNazgul

Burkholderia phage BcepNY3

Burkholderia phage KS10

Burkholderia phage KS9

Burkholderia phage phi1026b

Burkholderia phage phi644-2

chromosome

Burkholderia phage phiE12-2

chromosome

Burkholderia phage phiE125

Burkholderia phage phiE202

chromosome

Burkholderia phage phiE255

chromosomeBurkholderia

prophage phi52237

Cabbage leaf curl virus DNA

A

Cabbage leaf curl virus DNA

B

Cacao swollen shoot virus

California sea lion anellovirus

California sea lion

polyomavirus 1

Callitrichine herpesvirus 3

strain CJ0149

Camelpox virus

Campoletis

sonorensis

ichnovirus

chromosome

segment W

Campoletis sonorensis

ichnovirus segment $B$

Campoletis sonorensis

ichnovirus segment $\mathrm{C}$

Campoletis sonorensis

ichnovirus segment $D$

Campoletis sonorensis

ichnovirus segment $\mathrm{E}$ 
bioRxiv preprint doi: https://doi.org/10.1101/001727; this version posted January 10,2014 . The copyright holder for this preprint (which was not certified by peer review) is the author/funder, who has granted bioRxiv a license to display the preprint in perpetuity. It is made available under aCC-BY-NC-ND 4.0 International license.

SIANN: Strain Identification by Alignment to Near Neighbors

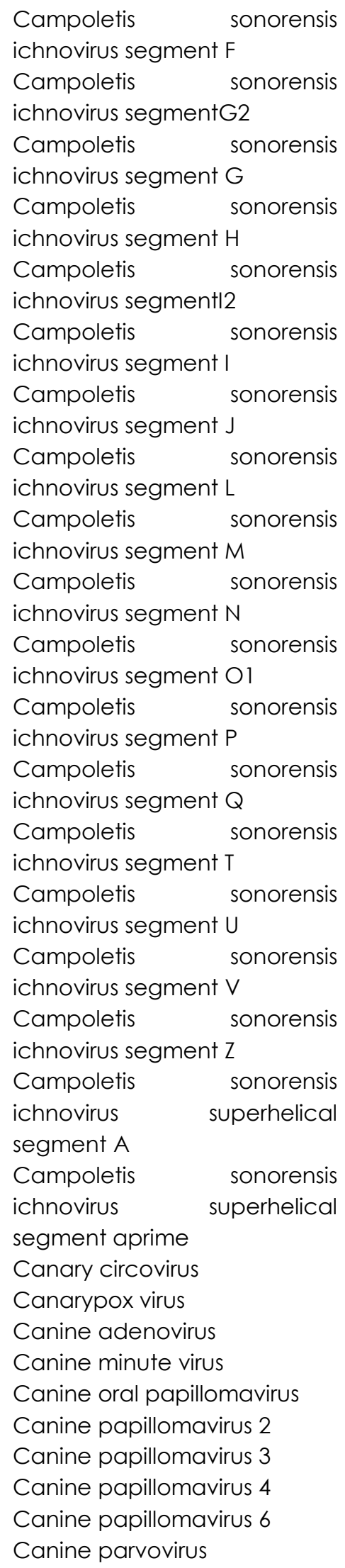

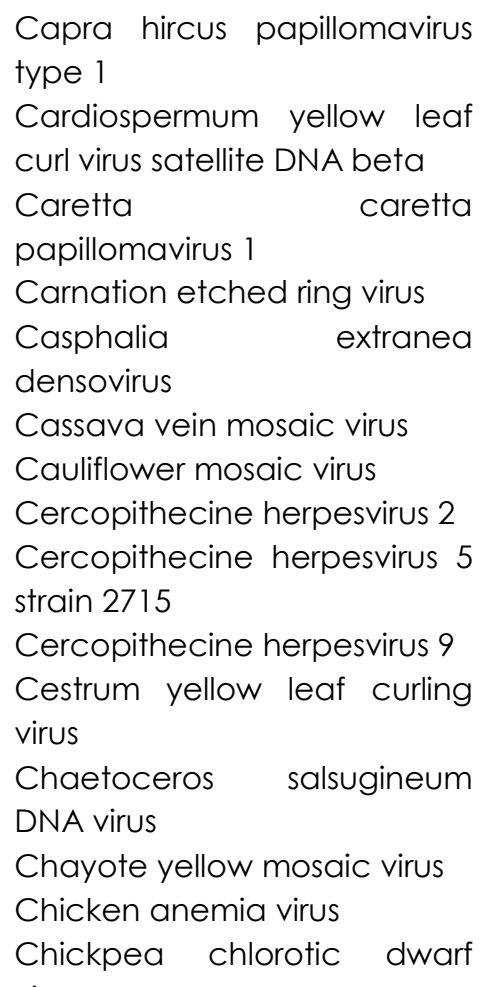

virus

Chilli leaf curl disease associated sequence virion

Chilli leaf curl Multan

alphasatellite

Chilli leaf curl virus

Chino del tomate virus DNA A

Chino del tomate virus DNA B

Chlamydia phage 3

Chlamydia phage 4

Chlamydia phage Chpl

Chlamydia phage Chp2

Chlamydia phage PhiCPG1

Chloris striate mosaic virus

Choristoneura fumiferana DEF MNPV

Choristoneura fumiferana

MNPV

Choristoneura occidentalis

granulovirus

Chrysodeixis chalcites

nucleopolyhedrovirus

Circovirus-like genome BBC-A

Circovirus-like genome CB-A

Circovirus-like genome CB-B

Circovirus-like genome RW-A

Circovirus-like genome RW-B

Circovirus-like genome RW-C

Circovirus-like genome RW-D
Circovirus-like genome RW-E

Circovirus-like genome SAR-A

Circovirus-like genome SAR-B

Citrus psorosis virus RNAl

Citrus psorosis virus RNA2

Citrus psorosis virus RNA3

Citrus yellow mosaic virus

Clanis

bilineata

nucleopolyhedrosis virus

Clavibacter phage CMP1

Clerodendron yellow mosaic

virus

Clerodendrum golden mosaic

China virus DNA A

Clerodendrum golden mosaic

China virus DNA B

Clerodendrum golden mosaic

virus DNA-A

Clerodendrum golden mosaic

virus DNA-B

Clostridium phage 39-O

Clostridium phage c-st

Clostridium phage phi3626

Clostridium phage phiC2

Clostridium phage phi CD 119

Clostridium phage phiCD27

Clostridium phage phiCTP1

Coconut foliar decay virus

Columbid circovirus

Commelina yellow mottle

virus

Corchorus golden mosaic

virus DNA-A

Corchorus golden mosaic

virus DNA-B

Corchorus yellow spot virus

DNA A

Corchorus yellow spot virus

DNA B

Corchorus yellow vein virusHoa Binh DNA A

Corchorus yellow vein virusHoa Binh DNA B

Corynebacterium phage

BFK20

Corynebacterium phage

P1201

Cotesia congregata

bracovirus segment Circle 10

Cotesia congregata

bracovirus segment Circlel 1 
bioRxiv preprint doi: https://doi.org/10.1101/001727; this version posted January 10,2014 . The copyright holder for this preprint (which was not certified by peer review) is the author/funder, who has granted bioRxiv a license to display the preprint in perpetuity. It is made available under aCC-BY-NC-ND 4.0 International license.

SIANN: Strain Identification by Alignment to Near Neighbors

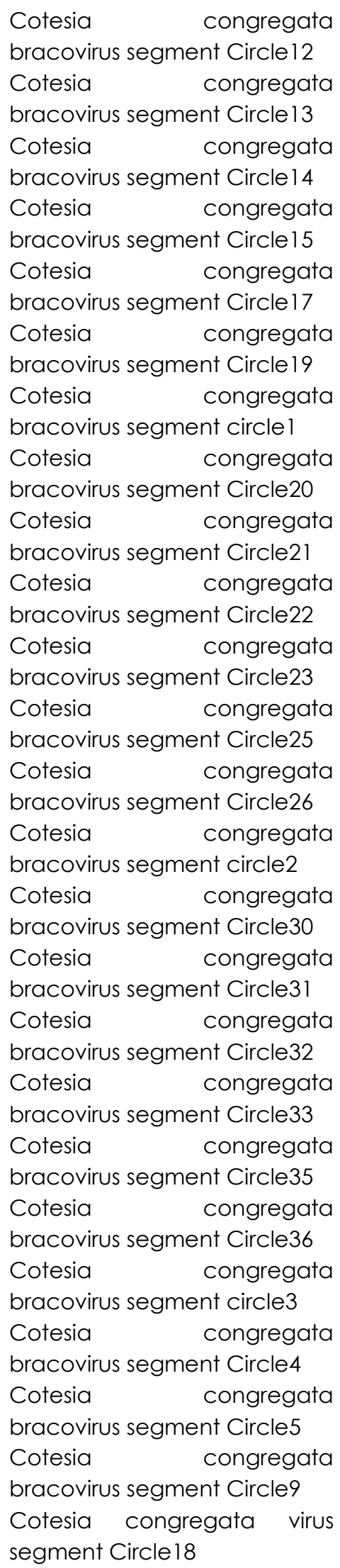

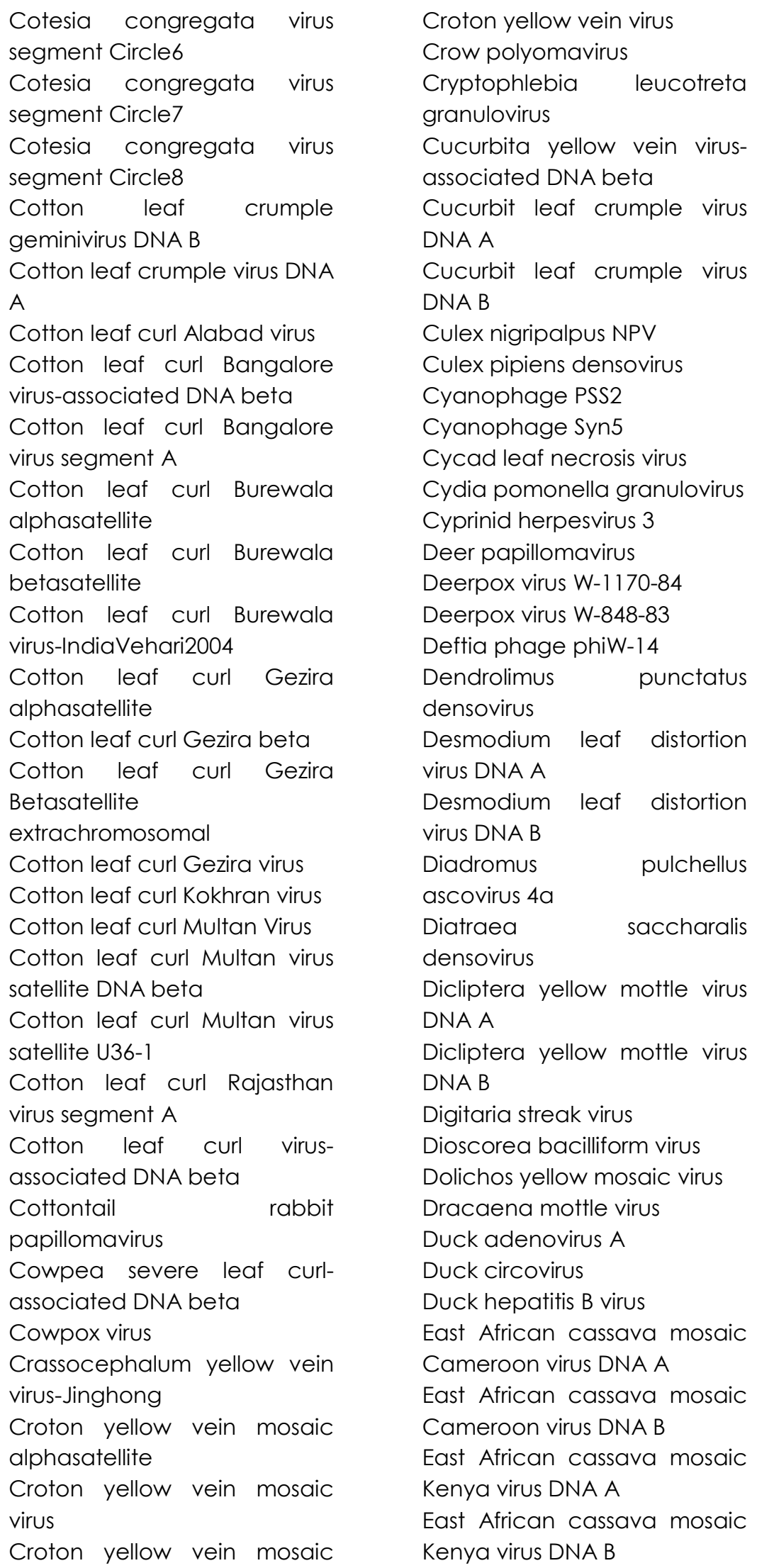

\author{
Cotesia congregata virus \\ Cotesia congregata virus \\ segment Circle7 \\ segment Circle8 \\ Cotton leaf crumple \\ geminivirus DNA B \\ Cotton leaf crumple virus DNA \\ Cotton leaf curl Alabad virus \\ Cotton leaf curl Bangalore \\ virus-associated DNA beta \\ virus segment $A$ \\ Cotton leaf curl Burewala \\ alphasatellite \\ Cotton leaf curl Burewala \\ betasatellite \\ Cotton leaf curl Burewala \\ virus-IndiaVehari2004 \\ Cotton leaf curl Gezira \\ alphasatellite \\ Cotton leaf curl Gezira beta \\ Cotton leaf curl Gezira \\ Betasatellite \\ extrachromosomal \\ Cotton leaf curl Gezira virus \\ Cotton leaf curl Kokhran virus \\ Cotton leaf curl Multan Virus \\ Cotton leaf curl Multan virus \\ beta \\ satellite U36-1 \\ Cotton leaf curl Rajasthan \\ segment $A$ \\ Cotton leaf curl virus- \\ associated DNA beta \\ Cottontail
}


bioRxiv preprint doi: https://doi.org/10.1101/001727; this version posted January 10,2014 . The copyright holder for this preprint (which was not certified by peer review) is the author/funder, who has granted bioRxiv a license to display the preprint in perpetuity. It is made available under aCC-BY-NC-ND 4.0 International license.

SIANN: Strain Identification by Alignment to Near Neighbors

East African cassava mosaic virus DNA A

East African cassava mosaic virus DNA B

East African cassava mosaic

Zanzibar virus DNA-A

East African cassava mosaic

Zanzibar virus DNA B

Ecotropis obliqua NPV

Ectocarpus siliculosus virus 1

Ectromelia virus

Emiliania huxleyi virus 86

Emilia yellow vein virus-

associated DNA beta

Emilia yellow vein virus-Fzl

Enterobacteria phage 13a

Enterobacteria phage 933W

Enterobacteria phage alpha3

Enterobacteria phage BA14

Enterobacteria phage BP-

4795

Enterobacteria phage

ECODS1

Enterobacteria phage EPS7

Enterobacteria phage

epsilon 15

Enterobacteria phage ES 18

Enterobacteria phage Felix 01

Enterobacteria phage Fels-2

Enterobacteria phage G4

Enterobacteria phage HKO22

Enterobacteria phage HK620

Enterobacteria phage HK97

Enterobacteria phage 12-2

Enterobacteria phage ID18

Enterobacteria phage ID2

MoscowID2001

Enterobacteria phage If 1

Enterobacteria phage lke

Enterobacteria phage IME08

Enterobacteria phage JKO6

Enterobacteria phage JS10

Enterobacteria phage JS98

Enterobacteria phage JSE

Enterobacteria phage K 1-5

Enterobacteria phage $\mathrm{K} 1 \mathrm{E}$

Enterobacteria phage K $1 \mathrm{~F}$

Enterobacteria phage

lambda

Enterobacteria phage LKAl

Enterobacteria phage M13
Enterobacteria phage Min27

Enterobacteria phage Mu

Enterobacteria phage N15

Enterobacteria phage N4

Enterobacteria phage $\mathrm{Pl}$

Enterobacteria phage P22

virus

Enterobacteria phage $\mathrm{P} 2$ virus

Enterobacteria phage P4

Enterobacteria phage Phi 1

Enterobacteria phage

phiEco32

Enterobacteria phage

phiEcoM-GJl

Enterobacteria phage phiP27

Enterobacteria phage

phiX174 sensu lato

Enterobacteria phage PRD 1

Enterobacteria phage PsP3

Enterobacteria phage RB 14

Enterobacteria phage RB 16

Enterobacteria phage RB43

Enterobacteria phage RB49

Enterobacteria phage RB51

Enterobacteria phage RB69

Enterobacteria phage RTP

Enterobacteria phage Sf6

Enterobacteria phage SfV

Enterobacteria phage SP6

Enterobacteria phage SSL-

2009 a

Enterobacteria phage ST104

Enterobacteria phage St-1

Enterobacteria phage ST64T

Enterobacteria phage $\mathrm{Tl}$

Enterobacteria phage T3

Enterobacteria phage T4

Enterobacteria phage T5

Enterobacteria phage T7

Enterobacteria phage TLS

Enterobacteria phage VT2-

Sakai

Enterobacteria phage WA13

Enterobacteria phage WV8

Enterobacteria phage YYZ-

2008

Enterococcus faecalis 62

chromosome

Enterococcus faecalis 62

plasmid EF62pA
Enterococcus faecalis 62

plasmid EF62pB

Enterococcus faecalis 62

plasmid EF62pC

Enterococcus phage EF62phi

Enterococcus phage EFAP-1

Enterococcus phage phiEf 11

Enterococcus phage

phiEF24C

Enterococcus phage phiFL IA

Enterococcus phage phifL2A

Enterococcus phage phiFL3A

Enterococcus phage phiFL4A

Enzootic nasal tumour virus of goats

Epiphyas postvittana NPV

Equid herpesvirus 1

Equid herpesvirus 2

Equid herpesvirus 4

Equid herpesvirus 9

Equine papillomavirus 2

Eragrostis curvula streak virus

Eragrostis streak virus

Erectites yellow mosaic virus

DNA-A

Erectites yellow mosaic virus satellite DNA beta

Erethizon dorsatum

papillomavirus type 1

Erinaceus europaeus

papillomavirus

Erwinia amylovora phage

Eral03

Erwinia phage phiEa21-4

Escherichia coli

bacteriophage rv5

Escherichia phage D108

Escherichia phage phiv10

Eupatorium vein clearing virus

Eupatorium yellow vein

associated DNA beta

Eupatorium yellow vein virus

Euphorbia leaf curl virus DNA

A

Euphorbia yellow mosaic virus

DNA A

Euphorbia yellow mosaic virus

DNA B

Euproctis pseudoconspersa

nucleopolyhedrovirus

European elk papillomavirus 
bioRxiv preprint doi: https://doi.org/10.1101/001727; this version posted January 10,2014 . The copyright holder for this preprint (which was not certified by peer review) is the author/funder, who has granted bioRxiv a license to display the preprint in perpetuity. It is made available under aCC-BY-NC-ND 4.0 International license.

SIANN: Strain Identification by Alignment to Near Neighbors

Faba bean necrotic stunt virus

DNA C

Faba bean necrotic stunt virus

DNA M

Faba bean necrotic stunt virus

DNA N

Faba bean necrotic stunt virus

DNA R

Faba bean necrotic stunt virus

DNAS

Faba bean necrotic stunt virus

DNA U1

Faba bean necrotic stunt virus

DNA U2

Faba bean necrotic stunt virus

DNA U4

Faba bean necrotic yellows

virus DNA 10

Faba bean necrotic yellows

virus DNA-1

Faba bean necrotic yellows

virus DNA 2

Faba bean necrotic yellows virus DNA 4

Faba bean necrotic yellows

virus DNA 5

Faba bean necrotic yellows

virus DNA 7

Faba bean necrotic yellows

virus DNA 8

Faba bean necrotic yellows

virus DNA 9

Faba bean necrotic yellows

Virus

Feldmannia species virus

Felid herpesvirus 1

Felis domesticus

papillomavirus type 1

Fenneropenaeus chinensis

hepatopancreatic densovirus

Figwort mosaic virus

Finch circovirus

Finch polyomavirus

Flavobacterium phage $11 \mathrm{~b}$

Fowl adenovirus A

Fowl adenovirus D

Fowlpox virus

Francolinus leucoscepus

papillomavirus 1

Fringilla

coelebs

papillomavirus
Frog adenovirus 1

Frog virus 3

Galleria mellonella densovirus

Gallid herpesvirus 1

Gallid herpesvirus 2

Gallid herpesvirus 3

Gammapapillomavirus

HPV127

Geobacillus phage GBSV 1

Geobacillus virus E2

Glossina pallidipes salivary

gland hypertrophy virus

Glypta fumiferanae ichnovirus

segmentA10

Glypta fumiferanae ichnovirus

segment Al

Glypta fumiferanae ichnovirus

segment A2

Glypta fumiferanae ichnovirus segment A3

Glypta fumiferanae ichnovirus segment A4

Glypta fumiferanae ichnovirus segment A5

Glypta fumiferanae ichnovirus segment A6

Glypta fumiferanae ichnovirus segment A7

Glypta fumiferanae ichnovirus segment A8

Glypta fumiferanae ichnovirus segment A9

Glypta fumiferanae ichnovirus segment B10

Glypta fumiferanae ichnovirus segment B11

Glypta fumiferanae ichnovirus segment B12

Glypta fumiferanae ichnovirus segment B13

Glypta fumiferanae ichnovirus segment B14

Glypta fumiferanae ichnovirus

segment B15

Glypta fumiferanae ichnovirus

segment B16

Glypta fumiferanae ichnovirus

segment B17

Glypta fumiferanae ichnovirus segment B18
Glypta fumiferanae ichnovirus segment B19

Glypta fumiferanae ichnovirus segment-B 1

Glypta fumiferanae ichnovirus segment B20

Glypta fumiferanae ichnovirus segment B21

Glypta fumiferanae ichnovirus segment B22

Glypta fumiferanae ichnovirus segment B23

Glypta fumiferanae ichnovirus segment B24

Glypta fumiferanae ichnovirus segment B25

Glypta fumiferanae ichnovirus segment B26

Glypta fumiferanae ichnovirus segment B27

Glypta fumiferanae ichnovirus segment B28

Glypta fumiferanae ichnovirus segment B29

Glypta fumiferanae ichnovirus segment-B2

Glypta fumiferanae ichnovirus segment B30

Glypta fumiferanae ichnovirus segment B31

Glypta fumiferanae ichnovirus segment B32

Glypta fumiferanae ichnovirus segment B33

Glypta fumiferanae ichnovirus segment B34

Glypta fumiferanae ichnovirus segment B35

Glypta fumiferanae ichnovirus segment B36

Glypta fumiferanae ichnovirus segment B37

Glypta fumiferanae ichnovirus segment B38

Glypta fumiferanae ichnovirus segment B39

Glypta fumiferanae ichnovirus segment-B3

Glypta fumiferanae ichnovirus segment B40 
bioRxiv preprint doi: https://doi.org/10.1101/001727; this version posted January 10,2014 . The copyright holder for this preprint (which was not certified by peer review) is the author/funder, who has granted bioRxiv a license to display the preprint in perpetuity. It is made available under aCC-BY-NC-ND 4.0 International license.

SIANN: Strain Identification by Alignment to Near Neighbors

Glypta fumiferanae ichnovirus segment B41

Glypta fumiferanae ichnovirus segment B42

Glypta fumiferanae ichnovirus segment B43

Glypta fumiferanae ichnovirus segment B44

Glypta fumiferanae ichnovirus segment B45

Glypta fumiferanae ichnovirus segment B46

Glypta fumiferanae ichnovirus segment B47

Glypta fumiferanae ichnovirus segment B48

Glypta fumiferanae ichnovirus segment B49

Glypta fumiferanae ichnovirus segment-B4

Glypta fumiferanae ichnovirus segment B50

Glypta fumiferanae ichnovirus segment B51

Glypta fumiferanae ichnovirus segment B52

Glypta fumiferanae ichnovirus segment B53

Glypta fumiferanae ichnovirus segment B54

Glypta fumiferanae ichnovirus segment B55

Glypta fumiferanae ichnovirus segment B56

Glypta fumiferanae ichnovirus segment B57

Glypta fumiferanae ichnovirus segment B58

Glypta fumiferanae ichnovirus segment B59

Glypta fumiferanae ichnovirus segment-B5

Glypta fumiferanae ichnovirus segment B60

Glypta fumiferanae ichnovirus segment B61

Glypta fumiferanae ichnovirus segment B62

Glypta fumiferanae ichnovirus segment B63
Glypta fumiferanae ichnovirus segment B64

Glypta fumiferanae ichnovirus segment B65

Glypta fumiferanae ichnovirus segment-B6

Glypta fumiferanae ichnovirus segment B7

Glypta fumiferanae ichnovirus segment B8

Glypta fumiferanae ichnovirus segment B9

Glypta fumiferanae ichnovirus segment $\mathrm{C} 10$

Glypta fumiferanae ichnovirus segment $\mathrm{C} 11$

Glypta fumiferanae ichnovirus segment $\mathrm{C} 12$

Glypta fumiferanae ichnovirus segment $\mathrm{C} 13$

Glypta fumiferanae ichnovirus segment $\mathrm{C} 14$

Glypta fumiferanae ichnovirus segment $\mathrm{C} 15$

Glypta fumiferanae ichnovirus segment $\mathrm{C} 16$

Glypta fumiferanae ichnovirus segment $\mathrm{C} 17$

Glypta fumiferanae ichnovirus segment $\mathrm{C} 18$

Glypta fumiferanae ichnovirus segment C19

Glypta fumiferanae ichnovirus segment-C1

Glypta fumiferanae ichnovirus segment C20

Glypta fumiferanae ichnovirus segment C21

Glypta fumiferanae ichnovirus segment C22

Glypta fumiferanae ichnovirus segment-C2

Glypta fumiferanae ichnovirus segment C3

Glypta fumiferanae ichnovirus segment C4

Glypta fumiferanae ichnovirus segment C5

Glypta fumiferanae ichnovirus segment $\mathrm{C6}$
Glypta fumiferanae ichnovirus segment C7

Glypta fumiferanae ichnovirus segment C8

Glypta fumiferanae ichnovirus segment C9

Glypta fumiferanae ichnovirus segment D1

Glypta fumiferanae ichnovirus segment D2

Glypta fumiferanae ichnovirus segment D3

Glypta fumiferanae ichnovirus segment D4

Glypta fumiferanae ichnovirus segment D5

Glypta fumiferanae ichnovirus segment D6

Glypta fumiferanae ichnovirus segment D7

Glypta fumiferanae ichnovirus segment El

Goatpox virus Pellor

Goose circovirus

Goose hemorrhagic

polyomavirus

Goose parvovirus

Gossypium darwinii

symptomless alphasatellite

DNA-alpha

Gossypium darwinii

symptomless virus DNA-A

Gossypium davidsonii

symptomless alphasatellite

DNA-alpha-B

Gossypium mustilinum

symptomless alphasatellite

DNA-alpha-B

Gossypium punctatum mild leaf curl virus DNA A

Gossypium punctatum mild leaf curl virus DNA B

Ground squirrel hepatitis virus

Gryllus bimaculatus nudivirus

Gull circovirus

Haemophilus phage HP1

Haemophilus phage HP2

Haloarcula hispanica

pleomorphic virus 1

Haloarcula phage SH 1

Halomonas phage phiHAP-1 
bioRxiv preprint doi: https://doi.org/10.1101/001727; this version posted January 10,2014 . The copyright holder for this preprint (which was not certified by peer review) is the author/funder, who has granted bioRxiv a license to display the preprint in perpetuity. It is made available under aCC-BY-NC-ND 4.0 International license.

SIANN: Strain Identification by Alignment to Near Neighbors

Halorubrum phage HF2

Halorubrum pleomorphic virus 1

Halovirus HF1

Hamster polyomavirus

Helicoverpa armigera

granulovirus

Helicoverpa armigera

multiple nucleopolyhedrovirus

Helicoverpa armigera-NPV

Helicoverpa armigera NPV

$\mathrm{NNgl}$

Helicoverpa armigera

nucleopolyhedrovirus G4

Helicoverpa zea SNPV

Heliothis virescens ascovirus

3e

Hepatitis $B$ virus

Heron hepatitis $B$ virus

Hisl virus

His2 virus

Hollyhock leaf crumple virus

Honeysuckle yellow vein

beta-JapanFukui2001

Honeysuckle yellow vein

mosaic beta-

JapanMiyizaki200 1

Honeysuckle yellow vein

mosaic disease associated

satellite DNA beta-lbaraki

Honeysuckle yellow vein

mosaic Virus

Honeysuckle yellow vein

mosaic virus-Kagoshima

Honeysuckle yellow vein

mosaic virus satellite DNA

beta

Honeysuckle yellow vein virus-

UK1

Horsegram yellow mosaic

Virus DNA B

Horsegram yellow mosaic

virus

Horseradish curly top virus

Human adenovirus 54

Human adenovirus AHuman

adenovirus Bl

Human adenovirus B2

Human adenovirus $C$

Human adenovirus $D$

Human adenovirus $\mathrm{E}$
Human adenovirus $F$

Human bocavirus 1

Human bocavirus 2

Human bocavirus 3

Human bocavirus 4

Human erythrovirus $\vee 9$

Human herpesvirus 1

Human herpesvirus 2

Human herpesvirus 3

Human herpesvirus 4

Human herpesvirus 5 strain

Merlin

Human herpesvirus 7

Human herpesvirus 8

Human papillomavirus- 18

Human papillomavirus 1

Human papillomavirus-2

Human papillomavirus 54

Human papillomavirus-5

Human papillomavirus type

101

Human papillomavirus type

103

Human papillomavirus type

108

Human papillomavirus type10

Human papillomavirus type 16

Human papillomavirus type 26

Human papillomavirus type 32

Human papillomavirus type 34

Human papillomavirus type 41

Human papillomavirus type 48

Human papillomavirus type 49

Human papillomavirus type- 4

Human papillomavirus type 50

Human papillomavirus type 53

Human papillomavirus type 60

Human papillomavirus type 63

Human papillomavirus type

$6 \mathrm{~b}$

Human papillomavirus type 7

Human papillomavirus type 88

Human papillomavirus type 90

Human papillomavirus type 92

Human papillomavirus type 96

Human papillomavirus type-9

Human parvovirus B19

Human T-lymphotropic virus 1

Human T-lymphotropic virus 4
Hyperthermophilic Archaeal

Virus 1

Hyperthermophilic Archaeal

Virus 2

Hyphantria

cunea

nucleopolyhedrovirus

Hyposoter fugitivus ichnovirus segment Al

Hyposoter fugitivus ichnovirus segment A2

Hyposoter fugitivus ichnovirus segment A3

Hyposoter fugitivus ichnovirus segment B10

Hyposoter fugitivus ichnovirus

segment B1 1

Hyposoter fugitivus ichnovirus segment B12

Hyposoter fugitivus ichnovirus segment B13

Hyposoter fugitivus ichnovirus segment B14

Hyposoter fugitivus ichnovirus segment B15

Hyposoter fugitivus ichnovirus segment B16

Hyposoter fugitivus ichnovirus segment B17

Hyposoter fugitivus ichnovirus segment B18

Hyposoter fugitivus ichnovirus segment-B 1

Hyposoter fugitivus ichnovirus segment B2

Hyposoter fugitivus ichnovirus segment B3

Hyposoter fugitivus ichnovirus segment B4

Hyposoter fugitivus ichnovirus segment B5

Hyposoter fugitivus ichnovirus segment B6

Hyposoter fugitivus ichnovirus segment B7

Hyposoter fugitivus ichnovirus segment B8

Hyposoter fugitivus ichnovirus segment B9

Hyposoter fugitivus ichnovirus segment $\mathrm{C} 10$ 
bioRxiv preprint doi: https://doi.org/10.1101/001727; this version posted January 10,2014 . The copyright holder for this preprint (which was not certified by peer review) is the author/funder, who has granted bioRxiv a license to display the preprint in perpetuity. It is made available under aCC-BY-NC-ND 4.0 International license.

SIANN: Strain Identification by Alignment to Near Neighbors

Hyposoter fugitivus ichnovirus segment $\mathrm{C} 11$

Hyposoter fugitivus ichnovirus segment $\mathrm{C} 12$

Hyposoter fugitivus ichnovirus segment $\mathrm{C} 13$

Hyposoter fugitivus ichnovirus segment $\mathrm{C} 14$

Hyposoter fugitivus ichnovirus segment $\mathrm{C} 15$

Hyposoter fugitivus ichnovirus segment $\mathrm{C} 16$

Hyposoter fugitivus ichnovirus segment $\mathrm{C} 17$

Hyposoter fugitivus ichnovirus segment $\mathrm{C} 18$

Hyposoter fugitivus ichnovirus segment $\mathrm{C} 19$

Hyposoter fugitivus ichnovirus segment- $\mathrm{C} 1$

Hyposoter fugitivus ichnovirus segment C20

Hyposoter fugitivus ichnovirus segment-C2

Hyposoter fugitivus ichnovirus segment $\mathrm{C} 3$

Hyposoter fugitivus ichnovirus segment $\mathrm{C} 4$

Hyposoter fugitivus ichnovirus segment $\mathrm{C5}$

Hyposoter fugitivus ichnovirus segment $\mathrm{C} 6$

Hyposoter fugitivus ichnovirus segment C7

Hyposoter fugitivus ichnovirus segment $\mathrm{C} 8$

Hyposoter fugitivus ichnovirus segment C9

Hyposoter fugitivus ichnovirus segment D10

Hyposoter fugitivus ichnovirus segment D1 1

Hyposoter fugitivus ichnovirus segment D12

Hyposoter fugitivus ichnovirus segment-D 1

Hyposoter fugitivus ichnovirus segment D2

Hyposoter fugitivus ichnovirus segment D3
Hyposoter fugitivus ichnovirus segment D4

Hyposoter fugitivus ichnovirus segment D5

Hyposoter fugitivus ichnovirus segment D6

Hyposoter fugitivus ichnovirus segment D7

Hyposoter fugitivus ichnovirus segment D8

Hyposoter fugitivus ichnovirus segment D9

Hyposoter fugitivus ichnovirus segment El

Hyposoter fugitivus ichnovirus segment E2

Hyposoter fugitivus ichnovirus segment $G 1$

Ictalurid herpesvirus 1 strain Auburn 1

Indian cassava mosaic virus DNA A

Indian cassava mosaic virus DNA B

Infectious hypodermal and hematopoietic necrosis virus Infectious spleen and kidney necrosis virus

Invertebrate iridescent virus 6 lodobacteriophage phiPLPE

Ipomoea yellow vein virus Jatropha leaf curl virus DNA A Jatropha yellow mosaic India virus DNA-A

JC polyomavirus

Junonia coenia densovirus

Kalanchoe top-spotting virus

Kenaf leaf curl virus DNA A

KI polyomavirus Stockholm 60

Klebsiella phage KP15

Klebsiella phage KP32

Klebsiella phage KP34

Klebsiella phage phiKO2

Kluyvera phage Kvpl

Kudzu mosaic virus DNA-A

Kudzu mosaic virus DNA-B

Lactobacillus johnsonii

prophage Lj771

Lactobacillus phage A2

Lactobacillus phage $\mathrm{KC} 5 \mathrm{a}$

Lactobacillus phage Lb338-1
Lactobacillus phage LC-Nu Lactobacillus phage LL-H Lactobacillus phage LP65 Lactobacillus phage Lrm 1 Lactobacillus phage LV-1 Lactobacillus phage phiAT3 Lactobacillus phage phigle Lactobacillus phage phiJL-1 Lactobacillus prophage Lj928 Lactobacillus prophage Lj965 Lactobacillus prophage phiadh

Lactococcus phage 1706 Lactococcus phage 4268 Lactococcus phage 712 Lactococcus phage asccphi28

Lactococcus phage blBB29 Lactococcus phage bIL 170 Lactococcus phage bIL67 Lactococcus phage BK5-T Lactococcus phage $c 2$ Lactococcus phage jj50 Lactococcus phage KSY 1 Lactococcus phage P008 Lactococcus phage P087 Lactococcus phage philC3 Lactococcus phage Q54 Lactococcus phage $\mathrm{rlt}$ Lactococcus phage sk 1 Lactococcus phage TP901-1 Lactococcus phage Tuc2009 Lactococcus phage ul36 Lactococcus prophage bIL285

Lactococcus prophage bIL286

Lactococcus prophage bIL309

Lactococcus prophage bIL310

Lactococcus prophage

bIL31 1

Lactococcus prophage

bIL312

Lamium leaf distortion associated virus Leucania separata nuclear polyhedrosis virus Leucas zeylanica yellow vein virus satellite DNA beta 
bioRxiv preprint doi: https://doi.org/10.1101/001727; this version posted January 10,2014 . The copyright holder for this preprint (which was not certified by peer review) is the author/funder, who has granted bioRxiv a license to display the preprint in perpetuity. It is made available under aCC-BY-NC-ND 4.0 International license.

SIANN: Strain Identification by Alignment to Near Neighbors

Lindernia anagallis yellow vein

virus DNA-A

Lindernia anagallis yellow vein

virus satellite DNA beta

Listeria phage A006

Listeria phage A118

Listeria phage A500

Listeria phage A51 1

Listeria phage B025

Listeria phage B054

Listeria phage P35

Listeria phage P40

Listonella phage phiHSIC

Loofa yellow mosaic virus

DNA A

Loofa yellow mosaic virus

DNA B

Lucky bamboo bacilliform

virus

Ludwigia leaf distortion

betasatellite

IndiaAmadalavalasaHibiscus2

007

Ludwigia yellow vein virusassociated DNA beta

Ludwigia yellow vein virus

DNA-A

Luffa begomovirus associated

DNA beta

Luffa puckering and leaf

distortion-associated DNA

beta

Lull virus

Lumpy skin disease virus $\mathrm{NI}-$

2490

Lymantria dispar MNPV

Lymantria xylina MNPV

Lymphocystis disease virus 1

Lymphocystis disease virus-

isolate China

Macacine herpesvirus 1

Macacine herpesvirus 3

Macacine herpesvirus 4

Macacine herpesvirus 5

Macaque simian foamy virus

Macroptilium golden mosaic

virus-

JamaicaWissadulaAugust

Town DNA A

Macroptilium golden mosaic virus-
JamaicaWissadulaAugust

Town DNA B

Macroptilium mosaic Puerto

Rico virus DNA A

Macroptilium mosaic Puerto

Rico virus DNA B

Macroptilium yellow mosaic

Florida virus DNA A

Macroptilium yellow mosaic

Florida virus DNA $B$

Macroptilium yellow mosaic

virus DNA A

Macroptilium yellow mosaic

virus DNA B

Maize streak virus-ASouth

Africa

Malachra yellow vein mosaic

virus-associated satellite DNA

beta

Mal de Rio Cuarto virus

segment 9

Malvastrum leaf curl

Guangdong virus

Malvastrum leaf curl virus-

associated defective DNA

beta

Malvastrum leaf curl virus-G87

Malvastrum yellow mosaic

virus-associated DNA 1

Malvastrum yellow mosaic

virus DNA-A

Malvastrum yellow mosaic

virus satellite DNA beta

Malvastrum yellow vein

Baoshan virus DNA-A

Malvastrum yellow vein-virus

Malvastrum yellow vein virus

satellite DNA beta

Malvastrum yellow vein

Yunnan-virus

Malvastrum yellow vein

Yunnan virus satellite DNA

beta

Mamestra configurata NPV-A

Mamestra configurata NPV-B

Mannheimia phage

phiMHaAl

Maruca vitrata MNPV

Mastomys

coucha

papillomavirus 2
Mastomys

natalensis

papillomavirus

Melanoplus sanguinipes

entomopoxvirus

Meleagrid herpesvirus 1

Melon chlorotic leaf curl virus

DNA A

Melon chlorotic mosaic virus-

associated alphasatellite

Melon chlorotic mosaic virus

DNA-A

Melon chlorotic mosaic virus

DNA-B

Merkel cell polyomavirus

Merremia mosaic virus DNA A

Merremia mosaic virus DNA B

Mesta yellow vein mosaic

Bahraich virus-

IndiaBahraich2007 DNA A

Mesta yellow vein mosaic virus-associated DNA beta

Mesta yellow vein mosaic virus DNA-A

Methanobacterium phage

psiM2

Methanothermobacter

prophage psiM100

Microbacterium phage Min 1

Microcystis phage Ma-LMMOI

Microplitis demolitor

bracovirus segment A

Microplitis demolitor

bracovirus segment B

Microplitis demolitor

bracovirus segment $C$

Microplitis demolitor

bracovirus segment $D$

Microplitis demolitor

bracovirus segment $\mathrm{E}$

Microplitis demolitor

bracovirus segment $\mathrm{F}$

Microplitis demolitor

bracovirus segment $G$

Microplitis demolitor

bracovirus segment $\mathrm{H}$

Microplitis demolitor

bracovirus segment I

Microplitis demolitor

bracovirus segment J

Microplitis demolitor

bracovirus segment $\mathrm{K}$ 
bioRxiv preprint doi: https://doi.org/10.1101/001727; this version posted January 10,2014 . The copyright holder for this preprint (which was not certified by peer review) is the author/funder, who has granted bioRxiv a license to display the preprint in perpetuity. It is made available under aCC-BY-NC-ND 4.0 International license.

SIANN: Strain Identification by Alignment to Near Neighbors

\begin{tabular}{|c|c|c|}
\hline \multirow{2}{*}{$\begin{array}{l}\text { Microplitis demolitor } \\
\text { bracovirus segment L } \\
\text { Microplitis demolitor } \\
\text { bracovirus segment M }\end{array}$} & \multirow{2}{*}{$\begin{array}{l}\text { Mungbean yellow mosaic } \\
\text { India virus DNA A } \\
\text { Mungbean yellow mosaic } \\
\text { India virus DNA B }\end{array}$} & \multirow{2}{*}{$\begin{array}{l}\text { Mycobacterium } \\
\text { Che9c } \\
\text { Mycobacterium } \\
\text { Che9d }\end{array}$} \\
\hline & & \\
\hline $\begin{array}{l}\text { Microplitis demolitor } \\
\text { bracovirus segment } \mathrm{N}\end{array}$ & $\begin{array}{l}\text { Mungbean yellow } \\
\text { virus DNA A }\end{array}$ & $\begin{array}{l}\text { Mycobacterium phage Cjwl } \\
\text { Mycobacterium phage }\end{array}$ \\
\hline $\begin{array}{l}\text { Microplitis demolitor } \\
\text { bracovirus segment } O\end{array}$ & $\begin{array}{l}\text { Mungbean yellow } \\
\text { virus DNA B }\end{array}$ & $\begin{array}{l}\text { Cooper } \\
\text { Mycobacterium }\end{array}$ \\
\hline $\begin{array}{l}\text { Milk vetch dwarf virus } \\
\text { segment } 10\end{array}$ & $\begin{array}{l}\text { Murid herpesvirus } 1 \\
\text { Murid herpesvirus } 2\end{array}$ & $\begin{array}{l}\text { Corndog } \\
\text { Mycobacterium phage CrimD }\end{array}$ \\
\hline $\begin{array}{l}\text { Milk vetch dwarf virus } \\
\text { segment } 11\end{array}$ & $\begin{array}{l}\text { Murid herpesvirus } 4 \\
\text { Murine adenovirus } 3\end{array}$ & $\begin{array}{l}\text { Mycobacterium phage D29 } \\
\text { Mycobacterium phage DD5 }\end{array}$ \\
\hline Milk vetch dwarf & Murine adenovirus A & Mycobacterium phage ET08 \\
\hline segment-1 & Murine pneumotropic virus & Mycobacterium phage \\
\hline $\begin{array}{l}\text { Milk vetch dwarf virus } \\
\text { segment } 2\end{array}$ & $\begin{array}{l}\text { Murine polyomavirus } \\
\text { Murine type C retrovirus }\end{array}$ & $\begin{array}{l}\text { Fruitloop } \\
\text { Mycobacterium phage Giles }\end{array}$ \\
\hline $\begin{array}{l}\text { Milk vetch dwarf virus } \\
\text { segment } 3\end{array}$ & $\begin{array}{l}\text { Musca domestica salivary } \\
\text { gland hypertrophy virus }\end{array}$ & $\begin{array}{l}\text { Mycobacterium phage } \\
\text { Gumball }\end{array}$ \\
\hline Milk vetch & Muscovy duck circovirus & Mycobacterium phage Halo \\
\hline segment 4 & Muscovy duck parvovirus & Mycobacterium phage \\
\hline $\begin{array}{l}\text { Milk vetch dwarf virus } \\
\text { segment } 5\end{array}$ & $\begin{array}{l}\text { Mus musculus papillomavirus } \\
\text { type } 1\end{array}$ & $\begin{array}{l}\text { Jasper } \\
\text { Mycobacterium phage KBG }\end{array}$ \\
\hline $\begin{array}{l}\text { Milk vetch dwarf virus } \\
\text { segment } 6\end{array}$ & $\begin{array}{l}\text { Mycobacterium phage } 244 \\
\text { Mycobacterium }\end{array}$ & $\begin{array}{l}\text { Mycobacterium phage } \\
\text { Konstantine }\end{array}$ \\
\hline $\begin{array}{l}\text { Milk vetch dwarf virus } \\
\text { segment } 7\end{array}$ & $\begin{array}{l}\text { Adjutor } \\
\text { Mycobacterium phage Angel }\end{array}$ & $\begin{array}{l}\text { Mycobacterium } \\
\text { Kostya }\end{array}$ \\
\hline $\begin{array}{l}\text { Milk vetch dwarf virus } \\
\text { segment } 8\end{array}$ & $\begin{array}{l}\text { Mycobacterium phage } \\
\text { angelica }\end{array}$ & $\begin{array}{l}\text { Mycobacterium phage } \mathrm{L} 5 \\
\text { Mycobacterium phage }\end{array}$ \\
\hline $\begin{array}{l}\text { Milk vetch dwarf virus } \\
\text { segment } 9\end{array}$ & $\begin{array}{l}\text { Mycobacterium } \\
\text { Ardmore }\end{array}$ & $\begin{array}{l}\text { LeBron } \\
\text { Mycobacterium phage Llij }\end{array}$ \\
\hline $\begin{array}{l}\text { Mimosa yellow leaf curl virus- } \\
\text { associated DNA } 1\end{array}$ & $\begin{array}{l}\text { Mycobacterium } \\
\text { Barnyard }\end{array}$ & $\begin{array}{l}\text { Mycobacterium phage } \\
\text { Lockley }\end{array}$ \\
\hline $\begin{array}{l}\text { Mimosa yellow leaf curl virus } \\
\text { DNA-A }\end{array}$ & $\begin{array}{l}\text { Mycobacterium } \\
\text { Bethlehem }\end{array}$ & $\begin{array}{l}\text { Mycobacterium } \\
\text { Myrna }\end{array}$ \\
\hline $\begin{array}{l}\text { Mimosa yellow leaf curl virus } \\
\text { satellite DNA beta }\end{array}$ & $\begin{array}{l}\text { Mycobacterium } \\
\text { Boomer }\end{array}$ & $\begin{array}{l}\text { Mycobacterium phage Nigel } \\
\text { Mycobacterium phage }\end{array}$ \\
\hline Minute virus of mice & Mycobacterium phage BPs & Omega \\
\hline Mirabilis mosaic virus & bacterium phage Brujita & Mycobacterium phage Orion \\
\hline Miscanthus streak virus-91 & Mycobacterium phage & Mycobacterium phage \\
\hline $\begin{array}{l}\text { Molluscum contagiosum virus } \\
\text { subtype } 1\end{array}$ & $\begin{array}{l}\text { Butterscotch } \\
\text { Mycobacterium phage Bxbl }\end{array}$ & $\begin{array}{l}\text { Pacc } 40 \\
\text { Mycobacterium phage PBI } 1\end{array}$ \\
\hline Monkeypox virus Zaire-96-I-16 & Mycobacterium phage Bxzl & Mycobacterium phage \\
\hline Morganella phage MmP1 & Mycobacterium phage Bxz2 & Peaches \\
\hline Mouse mammary tumor virus & Mycobacterium phage Cali & Mycobacterium phage PGl \\
\hline Mouse parvovirus 1 & Mycobacterium phage & Mycobacterium phage \\
\hline Mouse parvovirus 2 & Catera & Phaedrus \\
\hline Mouse parvovirus 3 & Mycobacterium phage Chah & Mycobacterium phage Phlyer \\
\hline Mouse parvovirus 4 & Mycobacterium phage & Mycobacterium \\
\hline Mouse parvovirus 5 & Che12 & Pipefish \\
\hline Mulard duck circovirus & Mycobacterium phage Che8 & $\begin{array}{l}\text { Mycobacterium phage PLot } \\
\text { Mycobacterium phage PMC }\end{array}$ \\
\hline
\end{tabular}


bioRxiv preprint doi: https://doi.org/10.1101/001727; this version posted January 10,2014 . The copyright holder for this preprint (which was not certified by peer review) is the author/funder, who has granted bioRxiv a license to display the preprint in perpetuity. It is made available under aCC-BY-NC-ND 4.0 International license.

SIANN: Strain Identification by Alignment to Near Neighbors

\begin{tabular}{|c|c|c|}
\hline $\begin{array}{l}\text { Mycobacterium phage Porky } \\
\begin{array}{ll}\text { Mycobacterium phage }\end{array}\end{array}$ & $\begin{array}{l}\text { Okra yellow mosaic Mexico } \\
\text { virus DNA B }\end{array}$ & $\begin{array}{l}\text { Pelargonium vein banding } \\
\text { virus }\end{array}$ \\
\hline $\begin{array}{l}\text { Predator } \\
\text { Mycobacterium phage }\end{array}$ & $\begin{array}{l}\text { Okra yellow vein disease } \\
\text { associated sequence virion }\end{array}$ & $\begin{array}{ll}\text { Penaeus } & \text { merguiensis } \\
\text { densovirus } & \end{array}$ \\
\hline Pukovnik & Okra yellow vein mosaic virus & Penaeus monodon \\
\hline $\begin{array}{l}\text { Mycobacterium } \\
\text { Qyrzula }\end{array}$ & $\begin{array}{l}\text { Old World harvest mouse } \\
\text { papillomavirus }\end{array}$ & $\begin{array}{l}\text { hepatopancreatic parvovirus } \\
\text { Pepper curly top virus }\end{array}$ \\
\hline Mycobacterium & Orangutan polyomavirus & Pepper golden mosaic virus \\
\hline Ramsey & Orf virus & DNA A \\
\hline Mycobacterium phage Rizal & Orgyia leucostigma NPV & Pepper golden mosaic virus \\
\hline Mycobacterium phage & Orgyia pseudotsugata MNPV & DNA B \\
\hline Rosebush & Oryctes rhinoceros virus & Pepper huasteco yellow vein \\
\hline Mycobacterium & Ostreid herpesvirus 1 & virus DNA A \\
\hline ScottMcG & Ostreococcus tauri virus 1 & Pepper huasteco yellow vein \\
\hline Mycobacterium phage Solon & Ostreococcus virus OsV5 & virus DNA B \\
\hline Mycobacterium phage Spud & Ovine adenovirus A & Pepper leaf curl Bangladesh \\
\hline Mycobacterium phage TM4 & Ovine adenovirus $D$ & virus segment A component \\
\hline Mycobacterium phage Troll4 & Ovine herpesvirus 2 & Pepper leaf curl virus DNA-A \\
\hline Mycobacterium phage & Ovine papillomavirus-1 & Pepper leaf curl virus satellite \\
\hline Tweety & Panicum streak virus-Karino & DNA beta \\
\hline Mycobacterium phage U2 & Panine herpesvirus 2 strain & Pepper leaf curl Yunnan virus \\
\hline Mycobacterium phage & Heberling & satellite DNA beta \\
\hline Wildcat & Papaya leaf curl China virus- & Pepper leaf curl Yunnan virus- \\
\hline Mycoplasma phage MAVI & G8 & YN323 \\
\hline $\begin{array}{l}\text { Mycoplasma phage P1 } \\
\text { Mycoplasma phage phiMFV1 }\end{array}$ & $\begin{array}{l}\text { Papaya leaf curl China virus } \\
\text { satellite DNA beta }\end{array}$ & Pepper yellow dwarf virus- \\
\hline Myotis polyomavirus VM-2008 & Papaya leaf curl Guandong & Pepper yellow leaf curl \\
\hline Mythimna loreyi densovirus & virus-GD2 DNA A & Indonesia virus DNA-A \\
\hline $\begin{array}{l}\text { Myxococcus phage Mx8 } \\
\text { Myxoma virus }\end{array}$ & $\begin{array}{l}\text { Papaya leaf curl virus- } \\
\text { associated DNA beta }\end{array}$ & $\begin{array}{l}\text { Pepper yellow leaf curl } \\
\text { Indonesia virus DNA-B }\end{array}$ \\
\hline Myzus persicae densovirus & Papaya leaf curl-virus & Pepper yellow vein Mali virus \\
\hline Nanovirus-like particle & Papiine herpesvirus 2 & Periplaneta fuliginosa \\
\hline Natrialba phage PhiCh1 & Paramecium & densovirus \\
\hline Neodiprion abietis NPV & Chlorella virus 1 & Petunia vein clearing virus \\
\hline Neodiprion lecontei NPV & Paramecium & Phage \\
\hline Neodiprion sertifer NPV & Chlorella virus AR 158 & Phage Gifsy-1 \\
\hline Oat dwarf virus & Paramecium & Phage Gifsy-2 \\
\hline OkLCV satDNA 10 & Chlorella virus FR483 & Phage phiJL001 \\
\hline $\begin{array}{l}\text { Okra leaf curl disease } \\
\text { associated DNA } 1\end{array}$ & $\begin{array}{ll}\text { Paramecium } & \text { bursaria } \\
\text { Chlorella virus NY2A } & \end{array}$ & $\begin{array}{l}\text { Phocoena } \\
\text { papillomavirus }\end{array}$ \\
\hline Okra leaf curl Mali & Parvovirus $\mathrm{Hl}$ & Phormidium phage Pf-WMP3 \\
\hline satellite DNA beta & Passionfruit severe & Phormidium phage Pf-WMP4 \\
\hline Okra leaf curl virus-Cameroon & distortion virus DNA-A & Phthorimaea operculella \\
\hline $\begin{array}{l}\text { Okra mottle virus-Brazilokra } \\
\text { DNA A }\end{array}$ & $\begin{array}{l}\text { Passionfruit severe leaf } \\
\text { distortion virus DNA-B }\end{array}$ & $\begin{array}{l}\text { granulovirus } \\
\text { Pieris rapae granulovirus }\end{array}$ \\
\hline $\begin{array}{l}\text { Okra mottle virus-Brazilokra } \\
\text { DNA B }\end{array}$ & $\begin{array}{l}\text { Pasteurella phage F108 } \\
\text { Peanut chlorotic streak virus }\end{array}$ & $\begin{array}{l}\text { Planaria asexual strain- } \\
\text { specific virus-like element }\end{array}$ \\
\hline $\begin{array}{l}\text { Okra yellow crinkle virus } \\
\text { segment A }\end{array}$ & $\begin{array}{l}\text { Pedilanthus leaf curl virus- } \\
\text { Pedilanthus }\end{array}$ & $\begin{array}{l}\text { type } 1 \text { large DNA segment } \\
\text { Planaria asexual strain- }\end{array}$ \\
\hline $\begin{array}{l}\text { Okra yellow mosaic Mexico } \\
\text { virus DNA A }\end{array}$ & PakistanMultan2004 & $\begin{array}{l}\text { specific virus-like element } \\
\text { type } 1 \text { small DNA segment }\end{array}$ \\
\hline
\end{tabular}


bioRxiv preprint doi: https://doi.org/10.1101/001727; this version posted January 10,2014 . The copyright holder for this preprint (which was not certified by peer review) is the author/funder, who has granted bioRxiv a license to display the preprint in perpetuity. It is made available under aCC-BY-NC-ND 4.0 International license.

SIANN: Strain Identification by Alignment to Near Neighbors

Planococcus citri densovirus Plutella xylostella granulovirus

Plutella xylostella multiple nucleopolyhedrovirus

Polyomavirus HPyV6

Polyomavirus HPyV7

Porcine adenovirus $C$

Porcine circovirus 1

Porcine circovirus 2

Porcine endogenous

retrovirus $E$

Porcine parvovirus

Potato apical leaf curl disease-associated satellite

DNA beta

Potato yellow mosaic

Panama virus DNA A

Potato yellow mosaic

Panama virus DNA B

Potato yellow mosaic Trinidad

virus DNA A

Potato yellow mosaic Trinidad

virus DNA B

Potato yellow mosaic virus

DNA A

Potato yellow mosaic virus

DNA B

Prochlorococcus phage P-

SSM4

Propionibacterium phage B5

Propionibacterium phage

PA6

Pseudaletia unipuncta

granulovirus

Pseudoalteromonas phage

PM2

Pseudocowpox virus

Pseudomonas phage 119X

Pseudomonas phage 14-1

Pseudomonas phage

201phi2-1

Pseudomonas phage 73

Pseudomonas phage B3

Pseudomonas phage D3112

Pseudomonas phage-D3

Pseudomonas phage DMS3

Pseudomonas phage EL

Pseudomonas phage F10

Pseudomonas phage F116

Pseudomonas phage $\mathrm{F} 8$

Pseudomonas phage gh- 1
Pseudomonas phage LBL3

Pseudomonas phage LIT1

Pseudomonas phage LKD16

Pseudomonas phage LMA2

Pseudomonas phage LUZ19

Pseudomonas phage LUZ24

Pseudomonas phage LUZ7

Pseudomonas phage M6

Pseudomonas phage MP22

Pseudomonas phage MP29

Pseudomonas phage MP38

Pseudomonas phage PAl 1

Pseudomonas phage PAJU2

Pseudomonas phage

PaP2Pseudomonas phage

$\mathrm{PaP} 3$

Pseudomonas phage PB 1

Pseudomonas phage Pf 1

Pseudomonas phage Pf3

Pseudomonas phage phi-2

Pseudomonas phage phiCTX

Pseudomonas phage phikF77

Pseudomonas phage phiKMV

Pseudomonas phage phiKZ

Pseudomonas phage PT2

Pseudomonas phage PT5

Pseudomonas phage SN

Pseudomonas phage YUA

Psittacid herpesvirus 1

Psittacus erithacus timneh

papillomavirus

Pumpkin yellow mosaic

Malaysia virus DNA A

Pyrobaculum spherical virus

Pyrococcus abyssi virus 1

Rabbit fibroma virus

Rabbit oral papillomavirus

Rachiplusia ou MNPV

Radish leaf curl virus satellite

DNA beta

Radish leaf curl virus segment

A

Ralstonia phage p12J

Ralstonia phage phiRSAl

Ralstonia phage RSB 1

Ralstonia phage RSL1

Ralstonia phage RSM1

Ralstonia phage RSM3

Ralstonia phage RSS 1

Ramie mosaic virus DNA-A

Ramie mosaic virus DNA-B
Ranid herpesvirus 1 strain McKinnell

Ranid herpesvirus 2 strain

ATCC VR-568

Rauscher murine leukemia

virus

Raven circovirus

RD11 4 retrovirus

Reticuloendotheliosis virus

Rhesus

monkey

papillomavirus

Rhizobium phage 16-3

Rhodothermus phage RM378

Rhynchosia golden mosaic

virus DNA A

Rhynchosia golden mosaic

virus DNA B

Rhynchosia golden mosaic

Yucatan virus DNA A

Rhynchosia golden mosaic

Yucatan virus DNA B

Rice tungro bacilliform virus

Roseobacter phage SIOI

Roseophage DSS3P2

Roseophage EE36P1

Rosss goose hepatitis $B$ virus

Rousettus aegyptiacus

papillomavirus type 1

Rudbeckia flower distortion

virus

Saccharum streak virus

Saimiriine herpesvirus 2

Salmonella enterica

bacteriophage SEl

Salmonella phage c341

Salmonella phage El

Salmonella phage epsilon34

Salmonella phage Fels-1

Salmonella phage phiSG-JL2

Salmonella phage SETP3

Salmonella phage ST64B

Sclerotinia sclerotiorum

hypovirulence associated

DNA virus 1

Sea turtle tornovirus 1

Senecio yellow mosaic virus

Sheeppox virus 17077-99

Sheldgoose hepatitis B virus

Shigella phage phiSboM-AG3

Shrimp white spot syndrome virus 
bioRxiv preprint doi: https://doi.org/10.1101/001727; this version posted January 10,2014 . The copyright holder for this preprint (which was not certified by peer review) is the author/funder, who has granted bioRxiv a license to display the preprint in perpetuity. It is made available under aCC-BY-NC-ND 4.0 International license.

SIANN: Strain Identification by Alignment to Near Neighbors

Sida golden mosaic Costa Rica virus DNA A

Sida golden mosaic Costa Rica virus DNA B

Sida golden mosaic Florida virus-Malvastrum DNA-A

Sida golden mosaic Florida virus-Malvastrum DNA-B

Sida golden mosaic Honduras virus DNA A

Sida golden mosaic Honduras virus DNA B

Sida golden mosaic virus

DNA-A

Sida golden mosaic virus DNA-B

Sida golden mottle virus DNA-

A

Sida golden mottle virus DNA-

B

Sida leaf curl virus-associated DNA 1

Sida leaf curl virus-associated DNA beta

Sida leaf curl-virus

Sida leaf curl virus satellite

DNA beta

Sida micrantha mosaic virus segment A

Sida micrantha mosaic virus segment B

Sida mosaic Sinaloa virus DNA

A

Sida mosaic Sinaloa virus DNA B

Sida mottle virus

Sida yellow mosaic virusChina-associated DNA beta DNA beta

Sida yellow mosaic-virus

Sida yellow mosaic Yucatan virus DNA A

Sida yellow mosaic Yucatan virus DNA B

Sida yellow vein disease associated DNA 1

Sida yellow vein Madurai virus Sida yellow vein Vietnam virus-associated DNA 1

Sida yellow vein Vietnam virus DNA-A
Sida yellow vein Vietnam virus

satellite DNA beta

Sida yellow vein virus DNA A

Sida yellow vein virus DNA B

Sida yellow vein virus satellite

DNA beta

Siegesbeckia yellow vein

Guangxi virus

Siegesbeckia yellow vein

virus-GD13-associated DNA

beta

Siegesbeckia yellow vein virus

GD13

Simian adenovirus 1

Simian adenovirus 3

Simian foamy virus 3

Simian immunodeficiency

virus SIV-mnd 2

Simian retrovirus 4

Simian T-cell lymphotropic virus 6

Simian T-lymphotropic virus 1

Simian T-lymphotropic virus 3

Simian virus 40

Singapore grouper iridovirus

Sinorhizobium phage PBC5

Small anellovirus 1

Small anellovirus 2

Snake parvovirus 1

Snow goose hepatitis $B$ virus

Sodalis phage phiSG1

Sodalis phage SO-1

South African cassava mosaic

virus DNA A

South African cassava mosaic

virus DNA B

Soybean chlorotic blotch virus

DNA A

Soybean chlorotic blotch virus

DNA B

Soybean chlorotic mottle virus

Soybean crinkle leaf virus

Soybean mild mottle virus

Spilanthes yellow vein virus

DNA-A

Spinach curly top virus

Spiroplasma kunkelii virus SkV1

CR2-3x

Spiroplasma phage 1-C74

Spiroplasma phage 1-R8A2B

Spiroplasma phage 4
Spiroplasma phage SVTS2

Spodoptera exigua MNPV

Spodoptera frugiperda

ascovirus 1 a

Spodoptera frugiperda MNPV

virus

Spodoptera litura granulovirus

Spodoptera litura NPV

Spodoptera

litura

nucleopolyhedrovirus II

Sputnik virophage

Squash leaf curl China virus-B

DNA-A

Squash leaf curl China virus-B

DNA B

Squash leaf curl Philippines

virus segment $A$

Squash leaf curl Philippines

virus segment $B$

Squash leaf curl virus $A$ component DNA

Squash leaf curl virus $B$ component DNA

Squash leaf curl Yunnan virus

Squash mild leaf curl virusImperial Valley DNA A

Squash mild leaf curl virusImperial Valley DNA B

Squash yellow mild mottle virus DNA B

Squirrel monkey polyomavirus

Sri Lankan cassava mosaic

virus DNA A

Sri Lankan cassava mosaic

virus DNA B

Stachytarpheta leaf curl virus

Staphylococcus phage 11

Staphylococcus phage 187

Staphylococcus phage 2638A

Staphylococcus phage 29

Staphylococcus phage 37

Staphylococcus phage $3 \mathrm{~A}$

Staphylococcus phage 42e

Staphylococcus phage

44AHJD

Staphylococcus phage 47

Staphylococcus phage 52A

Staphylococcus phage 53

Staphylococcus phage 55

Staphylococcus phage 66

Staphylococcus phage 69 
bioRxiv preprint doi: https://doi.org/10.1101/001727; this version posted January 10,2014 . The copyright holder for this preprint (which was not certified by peer review) is the author/funder, who has granted bioRxiv a license to display the preprint in perpetuity. It is made available under aCC-BY-NC-ND 4.0 International license.

SIANN: Strain Identification by Alignment to Near Neighbors

Staphylococcus phage 71

Staphylococcus phage 77

Staphylococcus phage

80 alpha

Staphylococcus phage 85

Staphylococcus phage 88

Staphylococcus phage 92

Staphylococcus phage 96

Staphylococcus phage

CNPH82

Staphylococcus phage EW

Staphylococcus phage GI

Staphylococcus phage K

Staphylococcus phage P954

Staphylococcus phage $\mathrm{PH} 15$

Staphylococcus phage

phi2958PVL

Staphylococcus phage

phiETA2

Staphylococcus phage

phiETA3

Staphylococcus phage-
phiETA

Staphylococcus phage

phiMR1 1

Staphylococcus phage

phiMR25

Staphylococcus phage

phiNM1

Staphylococcus phage

phiNM3

Staphylococcus phage

phip68

Staphylococcus phage

phiPVL108

Staphylococcus phage

phiPVL-CN125

Staphylococcus phage

phisauS-IPLA35

Staphylococcus phage

phiSauS-IPLA88

Staphylococcus phage phiSLT

Staphylococcus phage

PT1028

Staphylococcus phage ROSA

Staphylococcus phage SAP-

26

Staphylococcus phage SAP2

Staphylococcus phage Twort

Staphylococcus phage X2

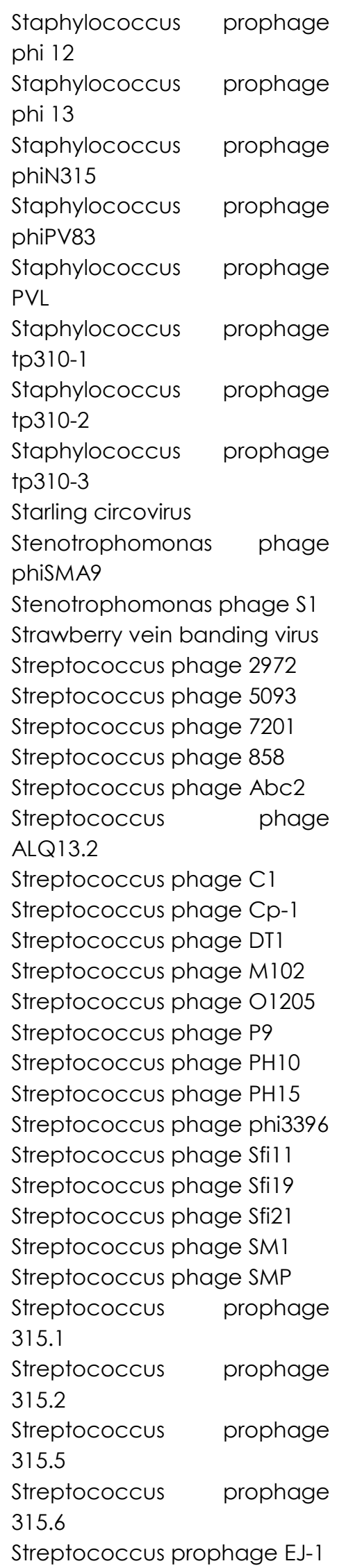

Streptococcus prophage

MM1

Streptococcus pyogenes

phage 315.3

Streptomyces phage mul6

Streptomyces phage phiBT1

Streptomyces phage phiC31

Streptomyces phage

phiSASDI

Streptomyces phage VWB

Stx 1 converting phage

Stx2-converting phage 1717

Stx2-converting phage 86

Stx2 converting phage- 1

Stx2 converting phage II

Subterranean clover stunt

virus DNA 1

Subterranean clover stunt

virus DNA 2

Subterranean clover stunt

virus DNA 3

Subterranean clover stunt

virus DNA 4

Subterranean clover stunt

virus DNA 5

Subterranean clover stunt

virus DNA 6

Subterranean clover stunt

virus DNA 7

Subterranean clover stunt

virus DNA 8

Sugarcane bacilliform IM virus

Sugarcane bacilliform Mor

virus

Sugarcane bacilliform virus

Sugarcane streak Egypt virus-

Giza

Sugarcane streak Reunion

virus

Sugarcane streak virus-Natal

Suid herpesvirus 1

Sulfolobus islandicus

filamentous virus

Sulfolobus islandicus rod-

shaped virus 1

Sulfolobus islandicus rod-

shaped virus 2

Sulfolobus spindle-shaped

virus 4

Sulfolobus spindle-shaped

virus 5 
bioRxiv preprint doi: https://doi.org/10.1101/001727; this version posted January 10,2014 . The copyright holder for this preprint (which was not certified by peer review) is the author/funder, who has granted bioRxiv a license to display the preprint in perpetuity. It is made available under aCC-BY-NC-ND 4.0 International license.

SIANN: Strain Identification by Alignment to Near Neighbors

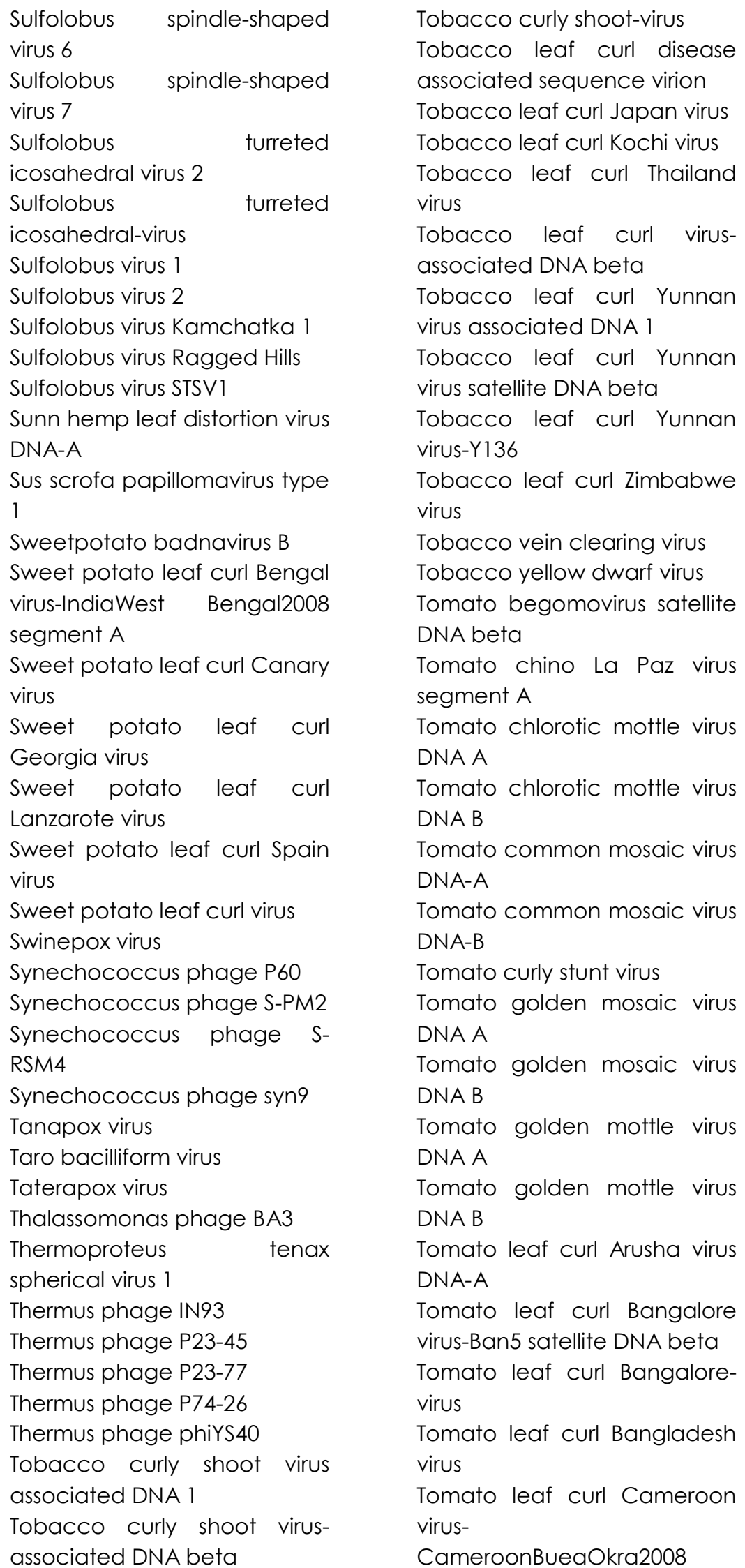

Tomato leaf curl Cebu virus DNA-A

Tomato leaf curl China virusG32 Tomato leaf curl Cotabato virus DNA-A

Tomato leaf curl Ghana virus segment $A$

Tomato leaf curl Guangdong virus DNA-A

Tomato leaf curl Guangxi virus Tomato leaf curl Gujarat virusVaranasi segment A

Tomato leaf curl Gujarat virusVaranasi segment $B$

Tomato leaf curl Hainan virus Tomato leaf curl Hsinchu virusTaiwanHsinchu2005 DNA A Tomato leaf curl Iran virus Tomato leaf curl Java virusAgeratum satellite DNA Tomato leaf curl Java-virus Tomato leaf curl Joydebpur beta virus Tomato leaf curl Joydebpur virus DNA-A

Tomato leaf curl Karnataka virus-associated DNA beta DNA-A

Tomato leaf curl Karnatakavirus Tomato leaf curl Kerala virus Tomato leaf curl Kumasi virus segment A

Tomato leaf curl Laos virus Tomato leaf curl Malaysia virus

Tomato leaf curl Mali virus Tomato leaf curl Mayotte virus Tomato leaf curl Mindanao virus DNA-A

Tomato leaf curl New Delhi virus-associated DNA beta Tomato leaf curl New Delhi virus DNA A

Tomato leaf curl New Delhi virus DNA B

Tomato leaf curl Nigeria virusNigeria2006

Tomato leaf curl Pakistan virus associated DNA 1 
bioRxiv preprint doi: https://doi.org/10.1101/001727; this version posted January 10,2014 . The copyright holder for this preprint (which was not certified by peer review) is the author/funder, who has granted bioRxiv a license to display the preprint in perpetuity. It is made available under aCC-BY-NC-ND 4.0 International license.

SIANN: Strain Identification by Alignment to Near Neighbors

Tomato leaf curl Pakistan virus

segment A

Tomato leaf curl Palampur

virus

Tomato leaf curl Patna virus

DNA-A

Tomato leaf curl Philippines

virus

Tomato leaf curl Philippine

virus satellite DNA beta

Tomato leaf curl Pune virus

Tomato leaf curl Seychelles

virus

Tomato leaf curl Sinaloa virus

DNA A

Tomato leaf curl Sinaloa virus

DNA B

Tomato leaf curl Sri Lanka

virus

Tomato leaf curl Sudan virus-

Gezira

Tomato leaf curl Sulawesi virus

DNA-A

Tomato leaf curl Taiwan virus

Tomato leaf curl Togo virus-

Togo2006

Tomato leaf curl Vietnam virus

DNA A

Tomato leaf curl virus-

associated DNA beta

Tomato leaf curl-virus

Tomato leaf curl virus-Pune-

associated DNA beta DNA-A

Tomato mild mosaic virus

DNA-A

Tomato mild mosaic virus

DNA-B

Tomato mild yellow leaf curl

Aragua virus DNA A

Tomato mild yellow leaf curl

Aragua virus DNA B

Tomato mosaic Havana virus

DNA A

Tomato mosaic Havana virus

DNA B

Tomato mosaic leaf curl virus

DNA A

Tomato mosaic leaf curl virus

DNA B

Tomato mottle Taino virus

DNA A
Tomato mottle Taino virus

DNA B

Tomato mottle virus DNA A

Tomato mottle virus DNA B

Tomato pseudo-curly top virus

Tomato rugose mosaic virus

DNA A

Tomato rugose mosaic virus

DNA B

Tomato severe leaf curl virus

Tomato severe rugose virus

DNA A

Tomato severe rugose virus

DNA B

Tomato yellow dwarf disease

associated satellite DNA

beta-Kochi virus

Tomato yellow leaf curl China virus associated DNA 1

Tomato yellow leaf curl

China-virus

Tomato yellow leaf curl Guangdong virus DNA-A

Tomato yellow leaf curl Indonesia virus-Lembang

Tomato yellow leaf curl Kanchanaburi virus DNA A

Tomato yellow leaf curl

Kanchanaburi virus DNA B

Tomato yellow leaf curl Mali

virus-associated DNA beta

Tomato yellow leaf curl Thailand virus associated DNA 1

Tomato yellow leaf curl

Thailand virus DNA A

Tomato yellow leaf curl

Thailand virus DNA B

Tomato yellow leaf curl

Vietnam virus DNA-A

Tomato yellow leaf curl

Vietnam virus satellite DNA

beta

Tomato yellow leaf curl virus-

associated DNA beta

Tomato yellow margin leaf

curl virus DNA A

Tomato yellow margin leaf

curl virus DNA B

Tomato yellow spot virus DNA-

A
Tomato yellow spot virus DNA-

B

Tomato yellow vein streak

virus DNA-A

Tomato yellow vein streak

virus DNA-B

Torque teno canis virus

Torque teno douroucouli virus

Torque teno felis virus

Torque teno midi virus 1

Torque teno midi virus 2

Torque teno mini virus 1

Torque teno mini virus 2

Torque teno mini virus 3

Torque teno mini virus 4

Torque teno mini virus 5

Torque teno mini virus 6

Torque teno mini virus 7

Torque teno mini virus 8

Torque teno mini virus 9

Torque teno sus virus 1

Torque teno tamarin virus

Torque teno virus 10

Torque teno virus 12

Torque teno virus 14

Torque teno virus 15

Torque teno virus 16

Torque teno virus 19

Torque teno virus- 1

Torque teno virus 25

Torque teno virus 26

Torque teno virus 27

Torque teno virus 28

Torque teno virus 3

Torque teno virus 4

Torque teno virus 6

Torque teno virus 7

Torque teno virus 8

Trichodysplasia spinulosa-

associated polyomavirus

Trichoplusia ni ascovirus $2 \mathrm{c}$

Trichoplusia ni SNPV

Tupaiid herpesvirus 1

Turkey adenovirus A

Turnip curly top virus

TYLCCNV-Y322 satellite DNA

beta

Urochloa streak virus

Vaccinia virus

Variola virus 
bioRxiv preprint doi: https://doi.org/10.1101/001727; this version posted January 10, 2014. The copyright holder for this preprint (which was not certified by peer review) is the author/funder, who has granted bioRxiv a license to display the preprint in perpetuity. It is made available under aCC-BY-NC-ND 4.0 International license.

SIANN: Strain Identification by Alignment to Near Neighbors

\author{
Velvet bean severe mosaic \\ virus DNA A \\ Velvet bean severe mosaic \\ virus DNA B \\ Vernonia yellow vein \\ betasatellite \\ Vernonia yellow vein virus \\ DNA-A \\ Vibrio phage fs 1 \\ Vibrio phage fs2 \\ Vibrio phage K139 \\ Vibrio phage kappa \\ Vibrio phage KSF-1 phi \\ Vibrio phage KVP40 \\ Vibrio phage N4 \\ Vibrio phage VEJphi \\ Vibrio phage $\mathrm{Vf} 12$ \\ Vibrio phage $\mathrm{VfO} 3 \mathrm{~K} 6$ \\ Vibrio phage VfO4K68 \\ Vibrio phage VGJphi \\ Vibrio phage VHML
}

\author{
Vibrio phage VP2 \\ Vibriophage VP4 \\ Vibrio phage VP5 \\ Vibrio phage VP882 \\ Vibrio phage VP93 \\ Vibrio phage VpV262 \\ Vibrio phage VSK \\ Watermelon chlorotic stunt \\ virus DNA A \\ Watermelon chlorotic stunt \\ virus DNA B \\ Wheat dwarf virus \\ Wissadula golden mosaic St \\ Thomas Virus DNA A \\ Wissadula golden mosaic St \\ Thomas Virus DNA B \\ Woodchuck hepatitis virus \\ WU Polyomavirus \\ Xanthomonas phage Cflc \\ Xanthomonas phage OP1 \\ Xanthomonas phage OP2
}

Xanthomonas phage phiL7

Xanthomonas phage Xop411

Xanthomonas phage Xp10

Xanthomonas phage Xp15

Xenopus laevis endogenous

retrovirus Xen 1

Xestia c-nigrum granulovirus

Xylella phage Xfas53

Yaba-like disease virus

Yaba monkey tumor virus

Yersinia pestis phage

phiA1 122

Yersinia phage Berlin

Yersinia phage L-413C

Yersinia phage phiYeO3-12

Yersinia phage PY54

Zinnia leaf curl disease associated sequence virion

Zinnia leaf curl virusassociated DNA beta 
bioRxiv preprint doi: https://doi.org/10.1101/001727; this version posted January 10,2014 . The copyright holder for this preprint (which was not certified by peer review) is the author/funder, who has granted bioRxiv a license to display the preprint in perpetuity. It is made available under aCC-BY-NC-ND 4.0 International license.

SIANN: Strain Identification by Alignment to Near Neighbors

\section{Appendix 3: Bacterial Database}

Acaryochloris marina

$\mathrm{MBIC} 11017$

Acetobacter pasteurianus IFO

328301

Acetohalobium arabaticum

DSM 5501

Acholeplasma laidlawii PG 8A

Achromobacter xylosoxidans

A8

Acidaminococcus

fermentans DSM 20731

Acidaminococcus intestini

RyC MR95

Acidianus hospitalis W1

Acidilobus saccharovorans

34515

Acidimicrobium ferrooxidans

DSM 10331

Acidiphilium cryptum JF 5

Acidiphilium multivorum

AlU301

Acidithiobacillus caldus SM 1

Acidithiobacillus ferrivorans

SS3

Acidithiobacillus ferrooxidans

ATCC 23270

Acidobacterium capsulatum

ATCC 51196

Acidothermus cellulolyticus

$11 \mathrm{~B}$

Acidovorax avenae subsp

avenae ATCC 19860

Acidovorax citrulli AACOO 1

Acidovorax ebreus TPSY

Acidovorax sp JS42

Aciduliprofundum boonei

T469

Acinetobacter baumannii

16562

Acinetobacter calcoaceticus

PHEA 2

Acinetobacter oleivorans DR 1

Acinetobacter $\mathrm{sp}$ ADP 1

Actinobacillus

pleuropneumoniae serovar

$5 \mathrm{~b}$ str L20

Actinobacillus succinogenes

$130 z$

Actinoplanes sp SE50 110
Actinosynnema mirum DSM

43827

Aerococcus urinae ACS $120 \mathrm{~V}$

Colloa

Aeromonas hydrophila subsp

hydrophila ATCC 7966

Aeromonas salmonicida

subsp salmonicida A449

Aeromonas veronii B565

Aeropyrum pernix K1

Aggregatibacter

actinomycetemcomitans

DIIS 1

Aggregatibacter aphrophilus

NJ8700

Agrobacterium fabrum str

C58

Agrobacterium radiobacter

K84

Agrobacterium sp H13 3

Agrobacterium vitis $\$ 4$

Akkermansia muciniphila

ATCC BAA 835

Alcanivorax borkumensis SK2

Alicycliphilus denitrificans $B C$

Alicyclobacillus

acidocaldarius subsp

acidocaldarius DSM 446

Aliivibrio salmonicida LFI1238

Alkalilimnicola ehrlichii MLHE 1

Alkaliphilus metalliredigens

QYMF

Alkaliphilus oremlandii OhILAs

Allochromatium vinosum DSM

180

Alteromonas macleodii str

Deep ecotype

Alteromonas sp SN2

Aminobacterium

colombiense DSM 12261

Ammonifex degensii KC4

Amycolatopsis mediterranei

U32

Amycolicicoccus subflavus

DQS3 9A1

Anabaena variabilis ATCC

29413

Anaerococcus prevotii DSM 20548
Anaerolinea thermophila UNI

1

Anaeromyxobacter

dehalogenans 2CP 1

Anaeromyxobacter sp Fw109

5

Anaplasma centrale str Israel

Anaplasma marginale str

Florida

Anaplasma phagocyłophilum

$\mathrm{HZ}$

Anoxybacillus flavithermus

WK 1

Aquifex aeolicus VF5

Arcanobacterium

haemolyticum DSM 20595

Archaeoglobus fulgidus DSM

4304

Archaeoglobus profundus

DSM 5631

Archaeoglobus veneficus

SNP6

Arcobacter butzleri RM4018

Arcobacter nitrofigilis DSM 7299

Arcobacter sp L

Aromatoleum aromaticum

EbN1

Arthrobacter arilaitensis Rel17

Arthrobacter aurescens TC 1

Arthrobacter

chlorophenolicus A6

Arthrobacter

phenanthrenivorans Sphe3

Arthrobacter sp FB24

Aster yellows witches broom

phytoplasma AYWB

Asticcacaulis excentricus $C B$

48

Atopobium parvulum DSM

20469

Azoarcus sp BH72

Azorhizobium caulinodans

ORS 571

Azospirillum sp B510

Azotobacter vinelandii DJ

Bacillus amyloliquefaciens

DSM 7

Bacillus anthracis str Ames 
bioRxiv preprint doi: https://doi.org/10.1101/001727; this version posted January 10,2014 . The copyright holder for this preprint (which was not certified by peer review) is the author/funder, who has granted bioRxiv a license to display the preprint in perpetuity. It is made available under aCC-BY-NC-ND 4.0 International license.

SIANN: Strain Identification by Alignment to Near Neighbors

Bacillus atrophaeus 1942

Bacillus cellulosilyticus DSM

2522

Bacillus cereus 03BB 102

Bacillus clausii KSM K16

Bacillus coagulans 26

Bacillus cytotoxicus NVH 391

98

Bacillus halodurans C 125

Bacillus licheniformis DSM 13

ATCC 14580

Bacillus megaterium DSM 319

Bacillus mycoides DSM 2048

Bacillus pseudofirmus OF4

Bacillus pumilus SAFR 032

Bacillus selenitireducens

MLS10

Bacillus subtilis BSn5

Bacillus thuringiensis serovar berliner ATCC 10792

Bacillus weihenstephanensis KBAB4

Bacteriovorax marinus SJ

Bacteroides fragilis $\mathrm{YCH} 46$

Bacteroides helcogenes P 36

108

Bacteroides salanitronis DSM 18170

Bacteroides thetaiotaomicron

VPI 5482

Bacteroides vulgatus ATCC 8482

Bartonella bacilliformis KC583

Bartonella clarridgeiae 73

Bartonella grahamii as4aup

Bartonella henselae str

Houston 1

Bartonella quintana str

Toulouse

Bartonella tribocorum CIP 105476

Baumannia cicadellinicola str Hc Homalodisca coagulata

Bdellovibrio bacteriovorus

HD100

Beijerinckia indica subsp indica ATCC 9039

Beutenbergia cavernae DSM 12333

Bifidobacterium adolescentis ATCC 15703
Bifidobacterium animalis

subsp animalis ATCC 25527

Bifidobacterium bifidum $\$ 17$

Bifidobacterium breve ACS

$071 \vee$ Sch8b

Bifidobacterium dentium Bdl

Bifidobacterium longum

DJO10A

Blattabacterium sp Blattella

germanica str Bge

Bordetella avium 197N

Bordetella bronchiseptica

RB50

Bordetella parapertussis 12822

Bordetella pertussis CS

Bordetella petrii DSM 12804

Borrelia afzelii PKo

Borrelia bissettii DN127

Borrelia burgdorferi B31

Borrelia duttonii Ly

Borrelia garinii PBi

Borrelia hermsii DAH

Borrelia recurrentis $\mathrm{Al}$

Borrelia turicatae 91E135

Brachybacterium faecium

DSM 4810

Brachyspira hyodysenteriae

WAl

Brachyspira intermedia PWS A

Brachyspira murdochii DSM

12563

Brachyspira pilosicoli 951000

Bradyrhizobium japonicum

USDA 110

Bradyrhizobium sp BTAi1

Brevibacillus brevis NBRC 100599

Brevundimonas subvibrioides

ATCC 15264

Brucella abortus A13334

Brucella canis ATCC 23365

Brucella melitensis bv 1 str $16 \mathrm{M}$

Brucella microti CCM 4915

Brucella ovis ATCC 25840

Brucella pinnipedialis B2 94

Brucella suis 1330

Buchnera aphidicola str APS

Acyrthosiphon pisum

Burkholderia ambifaria AMMD

Burkholderia cenocepacia HI2424
Burkholderia gladioli BSR3

Burkholderia glumae BGR 1

Burkholderia mallei ATCC

23344

Burkholderia multivorans

ATCC 17616

Burkholderia phymatum

STM815

Burkholderia phytofirmans

PsJN

Burkholderia pseudomallei

668

Burkholderia rhizoxinica HKI

454

Burkholderia sp 383

Burkholderia thailandensis E264

Burkholderia vietnamiensis $G 4$

Burkholderia xenovorans

LB400

Butyrivibrio proteoclasticus

B316

Caldicellulosiruptor bescii

DSM 6725

Caldicellulosiruptor

hydrothermalis 108

Caldicellulosiruptor

kristjanssonii 177R 1B

Caldicellulosiruptor

kronotskyensis 2002

Caldicellulosiruptor

lactoaceticus 6A

Caldicellulosiruptor obsidiansis

OB47

Caldicellulosiruptor

owensensis OL

Caldicellulosiruptor

saccharolyticus DSM 8903

Calditerrivibrio nitroreducens

DSM 19672

Caldivirga maquilingensis IC

167

Campylobacter concisus

13826

Campylobacter curvus 52592

Campylobacter fetus subsp

fetus 8240

Campylobacter hominis

ATCC BAA 381

Campylobacter jejuni subsp jejuni 81116 
bioRxiv preprint doi: https://doi.org/10.1101/001727; this version posted January 10,2014 . The copyright holder for this preprint (which was not certified by peer review) is the author/funder, who has granted bioRxiv a license to display the preprint in perpetuity. It is made available under aCC-BY-NC-ND 4.0 International license.

SIANN: Strain Identification by Alignment to Near Neighbors

Campylobacter lari RM2100

Candidatus Accumulibacter phosphatis clade IIA str UW 1

Candidatus Amoebophilus

asiaticus $5 \mathrm{a} 2$

Candidatus Arthromitus sp SFB

mouse Japan

Candidatus Azobacteroides

pseudotrichonymphae

genomovar CFP2

Candidatus Blochmannia

floridanus

Candidatus Carsonella ruddii

PV

Candidatus

Chloracidobacterium

thermophilum B

Candidatus Desulforudis

audaxviator MP104C

Candidatus Hamiltonella

defensa 5AT Acyrthosiphon

pisum

Candidatus Hodgkinia

cicadicola Dsem

Candidatus Korarchaeum

cryptofilum OPF8

Candidatus Koribacter

versatilis Ellin345

Candidatus Liberibacter

asiaticus str psy62

Candidatus Methylomirabilis

oxyfera

Candidatus Midichloria

mitochondrii Iric $V A$

Candidatus Moranella

endobia PCIT

Candidatus Nitrospira defluvii

Candidatus Pelagibacter sp

IMCC9063

Candidatus Phytoplasma

australiense

Candidatus Protochlamydia

amoebophila UWE25

Candidatus Puniceispirillum

marinum IMCC 1322

Candidatus Riesia

pediculicola USDA

Candidatus Ruthia magnifica

str $\mathrm{Cm}$ Calyptogena

magnifica
Candidatus Solibacter usitatus

Ellin6076

Candidatus Sulcia muelleri

GWSS

Candidatus Tremblaya

princeps PCIT

Candidatus Vesicomyosocius

okutanii HA

Candidatus Zinderia

insecticola CARI

Capnocytophaga canimorsus

Cc5

Capnocytophaga ochracea

DSM 7271

Carboxydothermus

hydrogenoformans Z 2901

Carnobacterium sp 174

Catenulispora acidiphila DSM

44928

Caulobacter crescentus CB15

Caulobacter segnis ATCC

21756

Caulobacter sp K31

Cellulomonas fimi ATCC 484

Cellulomonas flavigena DSM

20109

Cellulophaga algicola DSM

14237

Cellulophaga lytica DSM 7489

Cellvibrio gilvus ATCC 13127

Cellvibrio japonicus Ueda107

Cenarchaeum symbiosum A

Chelativorans sp BNCl

Chitinophaga pinensis DSM

2588

Chlamydia muridarum Nigg

Chlamydia trachomatis 434

Bu

Chlamydophila abortus $\$ 263$

Chlamydophila caviae GPIC

Chlamydophila felis Fe C 56

Chlamydophila pecorum E58

Chlamydophila pneumoniae

CWL029

Chlamydophila psittaci 6BC

Chlorobaculum parvum NClB

8327

Chlorobium chlorochromatii

CaD3

Chlorobium limicola DSM 245

Chlorobium luteolum DSM 273
Chlorobium

phaeobacteroides DSM 266

Chlorobium phaeovibrioides

DSM 265

Chlorobium tepidum TLS

Chloroflexus aggregans DSM

9485

Chloroflexus aurantiacus J 10

$\mathrm{fl}$

Chloroflexus sp Y $400 \mathrm{fl}$

Chloroherpeton thalassium

ATCC 35110

Chromobacterium violaceum

ATCC 12472

Chromohalobacter salexigens

DSM 3043

Citrobacter koseri ATCC BAA

895

Citrobacter rodentium ICC168

Clavibacter michiganensis

subsp michiganensis NCPPB

382

Clostridium acetobutylicum

ATCC 824

Clostridium beijerinckii NCIMB

8052

Clostridium botulinum A str

ATCC 3502

Clostridium cellulolyticum $\mathrm{H} 10$

Clostridium cellulovorans 743B

Clostridium difficile 630

Clostridium kluyveri DSM 555

Clostridium lentocellum DSM

5427

Clostridium ljungdahlii DSM

13528

Clostridium novyi NT

Clostridium perfringens ATCC

13124

Clostridium phytofermentans

ISDg

Clostridium saccharolyticum

WM1

Clostridium sp SY8519

Clostridium sticklandii DSM 519

Clostridium tetani E88

Clostridium thermocellum

ATCC 27405

Collimonas fungivorans Ter331

Colwellia psychrerythraea $34 \mathrm{H}$ 
bioRxiv preprint doi: https://doi.org/10.1101/001727; this version posted January 10,2014 . The copyright holder for this preprint (which was not certified by peer review) is the author/funder, who has granted bioRxiv a license to display the preprint in perpetuity. It is made available under aCC-BY-NC-ND 4.0 International license.

SIANN: Strain Identification by Alignment to Near Neighbors

Comamonas testosteroni CNB

2

Conexibacter woesei DSM

14684

Coprothermobacter

proteolyticus DSM 5265

Coraliomargarita akajimensis

DSM 45221

Coriobacterium glomerans

PW2

Corynebacterium

aurimucosum ATCC 700975

Corynebacterium diphtheriae

NCTC 13129

Corynebacterium efficiens YS

314

Corynebacterium

glutamicum ATCC 13032

Corynebacterium jeikeium

K411

Corynebacterium

kroppenstedtii DSM 44385

Corynebacterium

pseudotuberculosis FRC41

Corynebacterium resistens

DSM 45100

Corynebacterium ulcerans

809

Corynebacterium urealyticum

DSM 7109

Corynebacterium variabile

DSM 44702

Coxiella burnetii RSA 493

Croceibacter atlanticus

HTCC2559

Cronobacter sakazakii ATCC

BAA 894

Cronobacter turicensis z3032

Cryptobacterium curtum DSM

15641

Cupriavidus metallidurans

$\mathrm{CH} 34$

Cupriavidus necator $\mathrm{N} 1$

Cupriavidus taiwanensis LMG

19424

cyanobacterium UCYN A

Cyanothece sp ATCC 51142

Cyclobacterium marinum

DSM 745

Cytophaga hutchinsonii

ATCC 33406

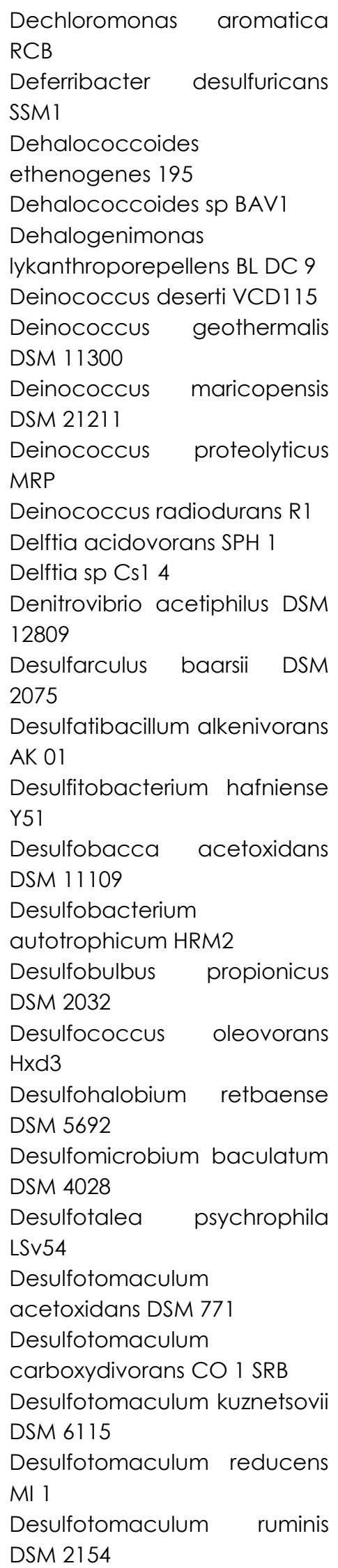

Desulfovibrio aespoeensis

Aspo 2

Desulfovibrio africanus str

Walvis Bay

Desulfovibrio alaskensis G20

Desulfovibrio desulfuricans

ND132

Desulfovibrio magneticus RS 1

Desulfovibrio salexigens DSM

2638

Desulfovibrio vulgaris $\mathrm{RCH}$

Desulfurispirillum indicum $\mathrm{S} 5$

Desulfurivibrio alkaliphilus

AHT2

Desulfurobacterium

thermolithotrophum

DSM

11699

Desulfurococcus

kamchatkensis $1221 \mathrm{n}$

Desulfurococcus mucosus

DSM 2162

Dichelobacter nodosus

VCS1703A

Dickeya dadantii 3937

Dickeya zeae Ech1591

Dictyoglomus thermophilum $\mathrm{H}$

612

Dictyoglomus turgidum DSM

6724

Dinoroseobacter shibae DFL

12

Dyadobacter fermentans

DSM 18053

Edwardsiella ictaluri 93146

Edwardsiella tarda EIB202

Eggerthella lenta DSM 2243

Eggerthella sp YY7918

Ehrlichia canis str Jake

Ehrlichia chaffeensis str

Arkansas

Ehrlichia ruminantium str

Welgevonden

Elusimicrobium minutum

Peil91

Enterobacter aerogenes

KCTC 2190

Enterobacter asburiae LF7a

Enterobacter cloacae subsp

cloacae ATCC 13047

Enterobacter sp 638

Enterococcus faecalis V583 
bioRxiv preprint doi: https://doi.org/10.1101/001727; this version posted January 10,2014 . The copyright holder for this preprint (which was not certified by peer review) is the author/funder, who has granted bioRxiv a license to display the preprint in perpetuity. It is made available under aCC-BY-NC-ND 4.0 International license.

SIANN: Strain Identification by Alignment to Near Neighbors

Erwinia amylovora ATCC
49946
Erwinia billingiae Eb661
Erwinia pyrifoliae DSM 12163
Erwinia sp Ejp617
Erwinia tasmaniensis E†1 99
Erysipelothrix rhusiopathiae
Erythrobacter
HTCC2594 litoralis
Escherichia coli O157:H7 str
Sakai
Escherichia fergusonii ATCC
35469

Ethanoligenens harbinense YUAN 3

Eubacterium eligens ATCC 27750

Eubacterium limosum KIST612

Eubacterium rectale ATCC 33656

Exiguobacterium sibiricum 255 15

Exiguobacterium sp ATlb

Ferrimonas balearica DSM

9799

Ferroglobus placidus DSM 10642

Fervidobacterium nodosum R+17 B1

Fibrobacter succinogenes

subsp succinogenes S85

Filifactor alocis ATCC 35896

Finegoldia magna ATCC 29328

Flavobacteriaceae

bacterium 351910

Flavobacterium

branchiophilum FL 15

Flavobacterium columnare

ATCC 49512

Flavobacterium johnsoniae

UW101

Flavobacterium

psychrophilum JIP02 86

Flexistipes sinusarabici DSM

4947

Fluviicola taffensis DSM 16823

Francisella novicida U1 12

Francisella philomiragia subsp

philomiragia ATCC 25017

Francisella sp TX077308
Francisella tularensis subsp

holarctica LVS

Frankia alni $\mathrm{ACN} 14 \mathrm{a}$

Frankia sp Ccl3

Frankia symbiont of Datisca

glomerata

Fusobacterium nucleatum

subsp nucleatum ATCC 25586

Gallibacterium anatis UMN179

Gallionella capsiferriformans

ES 2

gamma proteobacterium

HdNI

Gardnerella vaginalis 40905

Gemmatimonas aurantiaca $T$

27

Geobacillus kaustophilus

HTA426

Geobacillus sp C56 T3

Geobacillus

thermodenitrificans NG80 2

Geobacillus

thermoglucosidasius C56 YS93

Geobacillus thermoleovorans

CCB US3 UF5

Geobacter bemidjiensis Bem

Geobacter daltonii FRC 32

Geobacter lovleyi SZ

Geobacter metallireducens

GS 15

Geobacter sp M18

Geobacter sulfurreducens

PCA

Geobacter uraniireducens Rf4

Geodermatophilus obscurus

DSM 43160

Glaciecola nitratireducens

FR 1064

Glaciecola sp 4H 3 7YE 5

Gloeobacter violaceus PCC

7421

Gluconacetobacter

diazotrophicus PAI 5

Gluconacetobacter xylinus

NBRC 3288

Gluconobacter oxydans $621 \mathrm{H}$

Gordonia bronchialis DSM

43247

Gramella forsetii KT0803

Granulibacter bethesdensis CGDNIHI
Granulicella mallensis

MP5ACTX8

Granulicella tundricola

Haemophilus ducreyi $35000 \mathrm{HP}$

Haemophilus influenzae 10810

Haemophilus parainfluenzae

T3T1

Haemophilus parasuis SH0165

Haemophilus somnus 129PT

Hahella chejuensis KCTC 2396

Halalkalicoccus jeotgali B3

Halanaerobium

hydrogeniformans

Haliangium ochraceum DSM 14365

Haliscomenobacter hydrossis

DSM 1100

Haloarcula hispanica ATCC 33960

Haloarcula marismortui ATCC 43049

Halobacterium sp NRC 1

Haloferax volcanii DS2

Halogeometricum

borinquense DSM 11551

Halomicrobium mukohataei

DSM 12286

Halomonas elongata DSM

2581

halophilic archaeon DL31

Halopiger xanaduensis SH 6

Haloquadratum walsbyi C23

Halorhabdus utahensis DSM

12940

Halorhodospira halophila SL1

Halorubrum lacusprofundi

ATCC 49239

Haloterrigena turkmenica

DSM 5511

Halothermothrix orenii H 168

Halothiobacillus neapolitanus

c2

Helicobacter acinonychis str

Sheeba

Helicobacter bizzozeronii CIII 1

Helicobacter felis ATCC 49179

Helicobacter hepaticus ATCC 51449

Helicobacter mustelae 12198

Helicobacter pylori 26695 
bioRxiv preprint doi: https://doi.org/10.1101/001727; this version posted January 10,2014 . The copyright holder for this preprint (which was not certified by peer review) is the author/funder, who has granted bioRxiv a license to display the preprint in perpetuity. It is made available under aCC-BY-NC-ND 4.0 International license.

SIANN: Strain Identification by Alignment to Near Neighbors

Heliobacterium

modesticaldum Icel

Herbaspirillum seropedicae

SmR 1

Herminiimonas

arsenicoxydans

Herpetosiphon aurantiacus

DSM 785

Hippea maritima DSM 10411

Hirschia baltica ATCC 49814

Hydrogenobacter

thermophilus TK 6

Hydrogenobaculum $\mathrm{sp}$

Y04AAS 1

Hyperthermus butylicus DSM

5456

Hyphomicrobium denitrificans

ATCC 51888

Hyphomicrobium sp

Hyphomonas neptunium

ATCC 15444

Idiomarina loihiensis L2TR

Ignicoccus hospitalis KIN4 I

Ignisphaera aggregans DSM

17230

llyobacter polytropus DSM

2926

Intrasporangium calvum DSM

43043

Isoptericola variabilis 225

Isosphaera pallida ATCC

43644

Jannaschia sp CCS1

Janthinobacterium

$\mathrm{sp}$

Marseille

Jonesia denitrificans DSM

20603

Kangiella koreensis DSM 16069

Ketogulonicigenium vulgare WSH 001

Kineococcus radiotolerans

SRS30216

Kitasatospora setae KM 6054

Klebsiella oxytoca KCTC 1686

Klebsiella pneumoniae 342

Klebsiella variicola At 22

Kocuria rhizophila DC2201

Kosmotoga olearia TBF 1951

Kribbella flavida DSM 17836

Krokinobacter sp 4H 375

Kyrpidia tusciae DSM 2912
Kytococcus sedentarius DSM 20547

Lacinutrix sp 5H 374

Lactobacillus acidophilus

NCFM

Lactobacillus amylovorus GRL

1112

Lactobacillus brevis ATCC 367

Lactobacillus buchneri NRRL B

30929

Lactobacillus casei ATCC 334

Lactobacillus crispatus STI

Lactobacillus delbrueckii

subsp bulgaricus ATCC 11842

Lactobacillus fermentum IFO

3956

Lactobacillus gasseri ATCC 33323

Lactobacillus helveticus DPC 4571

Lactobacillus johnsonii NCC 533

Lactobacillus kefiranofaciens

ZW3

Lactobacillus plantarum

subsp plantarum ST III

Lactobacillus reuteri DSM

20016

Lactobacillus rhamnosus

ATCC 8530

Lactobacillus ruminis ATCC

27782

Lactobacillus sakei subsp

sakei 23K

Lactobacillus salivarius

UCC 118

Lactobacillus sanfranciscensis

TMW 11304

Lactococcus garvieae ATCC

49156

Lactococcus lactis subsp

cremoris NZ9000

Laribacter hongkongensis

HLHK9

Lawsonia intracellularis PHE

MN1 00

Leadbetterella byssophila

DSM 17132

Legionella longbeachae

NSW150
Legionella pneumophila subsp pneumophila ATCC

43290

Leifsonia xyli subsp xyli str СТCB07

Leptospira biflexa serovar Patoc strain Patoc 1 Ames

Leptospira borgpetersenii serovar Hardjo bovis str L550

Leptospira interrogans serovar Copenhageni str Fiocruz L1 130

Leptothrix cholodnii SP 6

Leptotrichia buccalis C 1013 b

Leuconostoc citreum KM20

Leuconostoc gasicomitatum

LMG 18811

Leuconostoc kimchii IMSNU

11154

Leuconostoc mesenteroides

subsp mesenteroides ATCC 8293

Leuconostoc sp C2

Listeria innocua Clip 1262

Listeria ivanovii

Listeria monocytogenes EGD

e

Listeria seeligeri serovar $12 \mathrm{~b}$

str SLCC3954

Listeria welshimeri serovar 6b

str SLCC5334

Lysinibacillus sphaericus C3 41

Macrococcus caseolyticus

JCSC5402

Magnetococcus marinus MC 1

Magnetospirillum

magneticum AMB 1

Mahella australiensis $501 \mathrm{BON}$

Mannheimia

sUcciniciproducens MBEL55E

Maribacter sp HTCC2170

Maricaulis maris MCS10

Marinithermus hydrothermalis

DSM 14884

Marinobacter adhaerens

HP15

Marinobacter aquaeolei VT8

Marinomonas mediterranea $M M B 1$ 
bioRxiv preprint doi: https://doi.org/10.1101/001727; this version posted January 10,2014 . The copyright holder for this preprint (which was not certified by peer review) is the author/funder, who has granted bioRxiv a license to display the preprint in perpetuity. It is made available under aCC-BY-NC-ND 4.0 International license.

SIANN: Strain Identification by Alignment to Near Neighbors

Marinomonas posidonica IVIA

Po 181

Marinomonas sp MWYL 1

Marivirga tractuosa DSM 4126

Megasphaera elsdenii

Meiothermus ruber DSM 1279

Meiothermus silvanus DSM

9946

Melissococcus plutonius ATCC

35311

Mesoplasma florum L1

Mesorhizobium ciceri biovar

biserrulae WSM1271

Mesorhizobium loti

MAFF303099

Mesorhizobium opportunistum

WSM2075

Metallosphaera cuprina Ar 4

Metallosphaera sedula DSM

5348

Methanobacterium sp AL 21

Methanobrevibacter

ruminantium

M1Methanobrevibacter

smithii ATCC 35061

Methanocaldococcus

fervens AG86

Methanocaldococcus

infernus ME

Methanocaldococcus

jannaschii DSM 2661

Methanocaldococcus sp

FS406 22

Methanocaldococcus

vulcanius $M 7$

Methanocella arvoryzae

MRE50

Methanocella paludicola

SANAE

Methanococcoides burtonii

DSM 6242

Methanococcus aeolicus

Nankai 3

Methanococcus maripaludis

S2

Methanococcus vannielii SB

Methanococcus voltae A3

Methanocorpusculum

labreanum Z

Methanoculleus marisnigri JR 1
Methanohalobium

evestigatum Z 7303

Methanohalophilus mahii DSM

5219

Methanoplanus petrolearius

DSM 11571

Methanopyrus kandleri AV19

Methanoregula boonei 6A8

Methanosaeta concilii GP6

Methanosaeta thermophila PT

Methanosalsum zhilinae DSM

4017

Methanosarcina acetivorans

C2A

Methanosarcina barkeri str

Fusaro

Methanosarcina mazei Go 1

Methanosphaera

stadtmanae DSM 3091

Methanosphaerula palustris

E1 9c

Methanospirillum hungatei JF

1

Methanothermobacter

marburgensis str Marburg

Methanothermobacter

thermautotrophicus str Delta

$\mathrm{H}$

Methanothermococcus

okinawensis $\mathrm{IHI}$

Methanothermus fervidus

DSM 2088

Methanotorris igneus Kol 5

Methylacidiphilum infernorum V4

Methylibium petroleiphilum

PMI

Methylobacillus flagellatus KT

Methylobacterium

chloromethanicum CM4

Methylobacterium extorquens

AM1

Methylobacterium nodulans

ORS 2060

Methylobacterium populi

BJ001

Methylobacterium

radiotolerans JCM 2831

Methylobacterium sp 446

Methylocella silvestris BL2
Methylococcus capsulatus str

Bath

Methylomicrobium

alcaliphilum

Methylomonas methanica

MC09

Methylotenera mobilis JLW8

Methylotenera versatilis 301

Methylovorus glucosetrophus

SIP3 4

Methylovorus sp MP688

Micavibrio aeruginosavorus

ARL 13

Microbacterium testaceum

StLB037

Micrococcus luteus NCTC

2665

Microcystis aeruginosa NIES

843

Microlunatus phosphovorus

NM 1

Micromonospora aurantiaca

ATCC 27029

Micromonospora sp L5

Mobiluncus curtisii ATCC

43063

Moorella thermoacetica

ATCC 39073

Moraxella catarrhalis RH4

Muricauda ruestringensis DSM

13258

Mycobacterium abscessus

ATCC 19977

Mycobacterium africanum

GM041182

Mycobacterium avium 104

Mycobacterium bovis AF2122

97

Mycobacterium canettii CIPT 140010059

Mycobacterium gilvum PYR GCK

Mycobacterium leprae TN

Mycobacterium marinum $M$

Mycobacterium rhodesiae

NBB3

Mycobacterium smegmatis str

MC2 155

Mycobacterium sp JDM601

Mycobacterium tuberculosis H37Rv 
bioRxiv preprint doi: https://doi.org/10.1101/001727; this version posted January 10,2014 . The copyright holder for this preprint (which was not certified by peer review) is the author/funder, who has granted bioRxiv a license to display the preprint in perpetuity. It is made available under aCC-BY-NC-ND 4.0 International license.

SIANN: Strain Identification by Alignment to Near Neighbors

\begin{tabular}{|c|c|c|}
\hline Mycobacterium & Neisseria lactamica 02006 & tsutsugamushi \\
\hline Agy99 & Neisseria meningitidis $\mathrm{MOl}$ & Boryong \\
\hline Mycobacterium vanbaalenii & 240149 & Oscillibacter valericigenes \\
\hline PYR 1 & Neorickettsia risticii str Illinois & Owenweeksia hongkongensis \\
\hline Mycoplasma agalactiae PG2 & Neorickettsia sennetsu str & DSM 17368 \\
\hline Mycoplasma arthritidis 158L3 1 & Miyayama & mucilaginosus \\
\hline Mycoplasma bovis PG45 & Niastella koreensis GR20 10 & KNP414 \\
\hline Mycoplasma capricolum & Nitratifractor salsuginis DSM & Paenibacillus polymyxa E681 \\
\hline subsp capricolum ATCC & 16511 & Paenibacillus sp JDR 2 \\
\hline 27343 & Nitratiruptor sp SB155 2 & Paenibacillus terrae HPL 003 \\
\hline Mycoplasma & Nitrobacter hamburgensis $\times 14$ & Paludibacter propionicigenes \\
\hline HRC 581 & Nitrobacter winogradskyi $\mathrm{Nb}$ & WB4 \\
\hline Mycoplasma crocodyli MP145 & 255 & Pantoea ananatis LMG 20103 \\
\hline Mycoplasma gallisepticum str & Nitrosococcus halophilus Nc4 & Pantoea sp At 9b \\
\hline Rlow & Nitrosococcus oceani ATCC & Pantoea vagans C9 1 \\
\hline Mycoplasma genitalium G37 & 19707 & Parabacteroides distasonis \\
\hline Mycoplasma haemocanis str & Nitrosococcus watsonii C 113 & ATCC 8503 \\
\hline Illinois & Nitrosomonas europaea & Parachlamydia \\
\hline Mycoplasma haemofelis str & ATCC 19718 & acanthamoebae UV 7 \\
\hline Langford 1 & Nitrosomonas eutropha C91 & Paracoccus denitrificans \\
\hline Mycoplasma hominis & Nitrosomonas sp AL212 & PD1222 \\
\hline Mycoplasma & Nitrosopumilus maritimus & Parvibaculum \\
\hline hyopneumoniae 232 & SCMI & lavamentivorans DS 1 \\
\hline Mycoplasma hyorhinis HUB 1 & Nitrosospira multiformis ATCC & Parvularcula bermudensis \\
\hline Mycoplasma leachii 990146 & 25196 & HTCC2503 \\
\hline Mycoplasma mobile 163K & Nocardia farcinica IFM 10152 & Pasteurella multocida subsp \\
\hline Mycoplasma mycoides subsp & Nocardioides sp JS614 & multocida str Pm70 \\
\hline mycoides SC str PG1 & Nocardiopsis dassonvillei & Pectobacterium atrosepticum \\
\hline Mycoplasma penetrans HF 2 & subsp dassonvillei DSM 43111 & SCRI1043 \\
\hline Mycoplasma pneumoniae & Nostoc azollae 0708 & Pectobacterium carotovorum \\
\hline M129 & Nostoc punctiforme & subsp carotovorum $\mathrm{PCl}$ \\
\hline Mycoplasma pulmonis UAB & 73102 & Pectobacterium wasabiae \\
\hline CTIP & Nostoc sp PCC 7120 & WPP163 \\
\hline Mycoplasma putrefaciens KSI & Novosphingobium & Pediococcus \\
\hline Mycoplasma suis str Illinois & aromaticivorans DSM 12444 & ATCC 25745 \\
\hline Mycoplasma synoviae 53 & Novosphingobium sp PPIY & Pedobacter heparinus DSM \\
\hline Myxococcus fulvus HW 1 & Oceanithermus profundus & 2366 \\
\hline Myxococcus xanthus DK 1622 & DSM 14977 & Pedobacter \\
\hline Nakamurella multipartita DSM & Oceanobacillus & 12145 \\
\hline 44233 & HTE831 & Pelagibacterium halotolerans \\
\hline Nanoarchaeum equitans Kin4 & Ochrobactrum & B2 \\
\hline M & ATCC 49188 & Pelobacter carbinolicus DSM \\
\hline Natranaerobius thermophilus & Odoribacter & 2380 \\
\hline JW NM WN LF & DSM 20712 & Pelobacter propionicus DSM \\
\hline Natrialba magadii & Oenococcus oeni PSU 1 & 2379 \\
\hline 43099 & Oligotropha carboxidovorans & Pelodictyon \\
\hline Natronomonas & OM5 & phaeoclathratiforme BU 1 \\
\hline DSM 2160 & Olsenella uli DSM 7084 & Pelotomaculum \\
\hline Nautilia profundicola AmH & Onion yellows phytoplasma & thermopropionicum SI \\
\hline Neisseria gonorrhoeae FA & OYM & Persephonella marina EX HI \\
\hline 1090 & Opitutus terrae PB90 1 & Petrotoga mobilis SJ95 \\
\hline
\end{tabular}


bioRxiv preprint doi: https://doi.org/10.1101/001727; this version posted January 10,2014 . The copyright holder for this preprint (which was not certified by peer review) is the author/funder, who has granted bioRxiv a license to display the preprint in perpetuity. It is made available under aCC-BY-NC-ND 4.0 International license.

SIANN: Strain Identification by Alignment to Near Neighbors

\begin{tabular}{|c|c|c|}
\hline $\begin{array}{l}\text { Phenylobacterium zucineum } \\
\text { HLKI }\end{array}$ & $\begin{array}{l}\text { Pseudomonas } \\
\text { brassicacearum }\end{array}$ & $\begin{array}{l}\text { Ramlibacter tataouinensis } \\
\text { TTB310 }\end{array}$ \\
\hline $\begin{array}{l}\text { Photobacterium profundum } \\
\text { ss9 }\end{array}$ & $\begin{array}{l}\text { brassicacearum NFM421 } \\
\text { Pseudomonas entomophila }\end{array}$ & $\begin{array}{l}\text { Renibacterium salmoninarum } \\
\text { ATCC } 33209\end{array}$ \\
\hline Photorhabdus asymbiotica & L48 & Rhizobium etli CFN 42 \\
\hline $\begin{array}{l}\text { subsp asymbiotica ATCC } \\
43949\end{array}$ & $\begin{array}{l}\text { Pseudomonas fluorescens } \\
\text { F113 }\end{array}$ & $\begin{array}{l}\text { Rhizobium leguminosarum bv } \\
\text { viciae } 3841\end{array}$ \\
\hline $\begin{array}{l}\text { Photorhabdus luminescens } \\
\text { subsp laumondii TTOl }\end{array}$ & $\begin{array}{l}\text { Pseudomonas fulva } 12 \mathrm{X} \\
\text { Pseudomonas mendocina }\end{array}$ & $\begin{array}{l}\text { Rhodobacter capsulatus SB } \\
1003\end{array}$ \\
\hline Picrophilus torridus DSM 9790 & ymp & Rhodobacter sphaeroides 241 \\
\hline Pirellula staleyi DSM 6068 & Pseudomonas protegens Pf 5 & Rhodococcus equi 1035 \\
\hline Planctomyces brasiliensis DSM & Pseudomonas putida Fl & Rhodococcus erythropolis PR4 \\
\hline 5305 & Pseudomonas stutzeri A1501 & Rhodococcus jostii RHAl \\
\hline $\begin{array}{l}\text { Planctomyces limnophilus } \\
\text { DSM } 3776\end{array}$ & $\begin{array}{l}\text { Pseudomonas syringae pv } \\
\text { phaseolicola 1448A }\end{array}$ & $\begin{array}{l}\text { Rhodococcus opacus B4 } \\
\text { Rhodoferax ferrireducens } T 118\end{array}$ \\
\hline $\begin{array}{l}\text { Polaromonas } \\
\text { naphthalenivorans CJ2 }\end{array}$ & $\begin{array}{l}\text { Pseudonocardia } \\
\text { dioxanivorans CB1 } 190\end{array}$ & $\begin{array}{l}\text { Rhodomicrobium vannielii } \\
\text { ATCC } 17100\end{array}$ \\
\hline Polaromonas sp JS666 & Pseudovibrio sp FO BEGl & Rhodopirellula baltica SH 1 \\
\hline $\begin{array}{l}\text { Polymorphum gilvum SL003B } \\
26 \mathrm{Al}\end{array}$ & $\begin{array}{l}\text { Pseudoxanthomonas spadix } \\
\text { BD a59 }\end{array}$ & $\begin{array}{l}\text { Rhodopseudomonas palustris } \\
\text { CGA009 }\end{array}$ \\
\hline Polynucleobacter necessarius & Pseudoxanthomonas & Rhodospirillum centenum SW \\
\hline subsp asymbioticus QLW & suwonensis 111 & Rhodospirillum rubrum ATCC \\
\hline PIDMWA 1 & Psychrobacter arcticus 2734 & 11170 \\
\hline $\begin{array}{l}\text { Porphyromonas } \\
\text { asaccharolytica DSM } 20707\end{array}$ & $\begin{array}{l}\text { Psychrobacter cryohalolentis } \\
\text { K5 }\end{array}$ & $\begin{array}{l}\text { Rhodothermus marinus DSM } \\
4252\end{array}$ \\
\hline Porphyromonas gingivalis W83 & Psychrobacter sp PRwf 1 & Rickettsia africae ESF 5 \\
\hline Prevotella denticola F0289 & Psychromonas ingrahamii 37 & Rickettsia akari str Hartford \\
\hline Prevotella melaninogenica & Pusillimonas sp T7 7 & Rickettsia bellii RML369 C \\
\hline ATCC 25845 & Pyrobaculum aerophilum str & Rickettsia canadensis \\
\hline Prevotella ruminicola 23 & IM2 & McKiel \\
\hline $\begin{array}{l}\text { Prochlorococcus marinus str } \\
\text { MIT } 9215\end{array}$ & $\begin{array}{l}\text { Pyrobaculum arsenaticum } \\
\text { DSM } 13514\end{array}$ & $\begin{array}{l}\text { Rickettsia conorii str Malish } 7 \\
\text { Rickettsia felis URRWXCal2 }\end{array}$ \\
\hline $\begin{array}{l}\text { Propionibacterium acnes } \\
6609\end{array}$ & $\begin{array}{l}\text { Pyrobaculum calidifontis JCM } \\
11548\end{array}$ & $\begin{array}{l}\text { Rickettsia heilongjiangensis } \\
054\end{array}$ \\
\hline $\begin{array}{l}\text { Propionibacterium } \\
\text { freudenreichii subsp shermanii }\end{array}$ & $\begin{array}{l}\text { Pyrobaculum islandicum DSM } \\
4184\end{array}$ & $\begin{array}{l}\text { Rickettsia japonica YH } \\
\text { Rickettsia massiliae MTL }\end{array}$ \\
\hline CIRM BIAI & Pyrobaculum & Rickettsia peacockii str Rustic \\
\hline Prosthecochloris aestuarii DSM & V24Sta & Rickettsia prowazekii str \\
\hline 271 & Pyrobaculum sp 1860 & Madrid E \\
\hline Proteus mirabilis HI432O & Pyrococcus abyssi GE5 & Rickettsia rickettsii str lowa \\
\hline Pseudoalteromonas atlantica & Pyrococcus furiosus DSM 3638 & Rickettsia sibirica 246 \\
\hline T6C & Pyrococcus horikoshii OT3 & Rickettsia slovaca 13 B \\
\hline Pseudoalteromonas & Pyrococcus sp NA2 & Rickettsia typhi str Wilmington \\
\hline haloplanktis TAC 125 & Pyrococcus yayanosii $\mathrm{CH}$ & Riemerella anatipestifer ATCC \\
\hline Pseudoalteromonas & Pyrolobus fumarii 1A & 11845 DSM 15868 \\
\hline SM9913 & Rahnella sp Y9602 & Robiginitalea \\
\hline Pseudogulbenkiania sp NH8B & Ralstonia eutropha JMP134 & HTCC2501 \\
\hline Pseudomonas aeruginosa & Ralstonia pickettii 12D & Roseburia hominis A2 183 \\
\hline PAOI & $\begin{array}{l}\text { Ralstonia } \quad \text { solanacearum } \\
\text { GMI1000 }\end{array}$ & $\begin{array}{l}\text { Roseiflexus castenholzii DSM } \\
13941 \\
\text { Roseiflexus sp RS 1 }\end{array}$ \\
\hline
\end{tabular}


bioRxiv preprint doi: https://doi.org/10.1101/001727; this version posted January 10,2014 . The copyright holder for this preprint (which was not certified by peer review) is the author/funder, who has granted bioRxiv a license to display the preprint in perpetuity. It is made available under aCC-BY-NC-ND 4.0 International license.

SIANN: Strain Identification by Alignment to Near Neighbors

\begin{tabular}{|c|c|c|}
\hline Roseobacter denitrificans & Shewanella & $\begin{array}{l}\text { Stackebrandtia } \\
\text { DSM } 44728\end{array}$ \\
\hline $\begin{array}{l}\text { Och } 114 \\
\text { Roseobacter litoralis Och } 149\end{array}$ & $\begin{array}{l}\text { WP3 } \\
\text { Shewanella putrefaciens CN }\end{array}$ & $\begin{array}{l}\text { DSM } 44728 \\
\text { Staphylococcus aureus subsp }\end{array}$ \\
\hline Rothia dentocariosa ATCC & & aureus $\mathrm{JHI}$ \\
\hline 17931 & Shewanella sediminis HAW & Staphylococcus carnosus \\
\hline Rothia mucilaginosa DY 18 & EB3 & subsp carnosus TM300 \\
\hline Rubrobacter xylanophilus & Shewanella sp ANA 3 & Staphylococcus epidermidis \\
\hline DSM 9941 & Shewanella violacea DSS 12 & ATCC 12228 \\
\hline Ruegeria pomeroyi DSS 3 & Shewanella woodyi ATCC & Staphylococcus haemolyticus \\
\hline Ruegeria sp TM1040 & 51908 & $\mathrm{JCSC} 1435$ \\
\hline Ruminococcus albus 7 & Shigella boydii Sb227 & Staphylococcus \\
\hline Runella slithyformis DSM 19594 & Shigella dysenteriae Sd197 & HKU09 01 \\
\hline Saccharomonospora viridis & Shigella flexneri 2a str 301 & Staphylococcus \\
\hline DSM 43017 & Shigella sonnei Ss046 & pseudintermedius HKU10 03 \\
\hline Saccharophagus degradans & Sideroxydans lithotrophicus ES & Staphylothermus hellenicus \\
\hline 240 & 1 & DSM 12710 \\
\hline Saccharopolyspora erythraea & Simkania negevensis Z & Staphylothermus marinus Fl \\
\hline NRRL 2338 & Sinorhizobium fredii NGR234 & Starkeya novella DSM 506 \\
\hline Salinibacter ruber DSM 13855 & Sinorhizobium medicae & Stenotrophomonas \\
\hline Salinispora arenicola CNS 205 & WSM419 & maltophilia K279a \\
\hline Salinispora tropica CNB 440 & Sinorhizobium meliloti 1021 & Stigmatella aurantiaca DW4 3 \\
\hline Salmonella bongori NCTC & Slackia heliotrinireducens DSM & 1 \\
\hline 12419 & 20476 & Streptobacillus \\
\hline $\begin{array}{l}\text { Salmonella enterica subsp } \\
\text { enterica serovar Enteritidis str }\end{array}$ & $\begin{array}{l}\text { Sodalis } \\
\text { morsitans }\end{array}$ & $\begin{array}{l}\text { DSM } 12112 \\
\text { Streptococcus }\end{array}$ \\
\hline P125109 & Sorangium cellulosum So ce56 & $2603 \vee R$ \\
\hline $\begin{array}{l}\text { Sanguibacter keddieii DSM } \\
10542\end{array}$ & $\begin{array}{l}\text { Sphaerobacter thermophilus } \\
\text { DSM } 20745\end{array}$ & $\begin{array}{l}\text { Streptococcus dysgalactiae } \\
\text { subsp equisimilis ATCC } 12394\end{array}$ \\
\hline $\begin{array}{l}\text { Sebaldella termitidis ATCC } \\
33386\end{array}$ & $\begin{array}{l}\text { Sphaerochaeta coccoides } \\
\text { DSM } 17374\end{array}$ & $\begin{array}{l}\text { Streptococcus equi } \\
\text { subspecies zooepidemicus }\end{array}$ \\
\hline $\begin{array}{l}\text { Segniliparus rotundus DSM } \\
44985\end{array}$ & $\begin{array}{l}\text { Sphaerochaeta globus str } \\
\text { Buddy }\end{array}$ & $\begin{array}{ll}\text { Streptococcus } & \text { gallolyticus } \\
\text { subsp gallolyticus } & \text { ATCC BAA }\end{array}$ \\
\hline $\begin{array}{l}\text { Selenomonas } \\
\text { ATCC } 35185\end{array}$ & $\begin{array}{l}\text { Sphaerochaeta pleomorpha } \\
\text { str Grapes }\end{array}$ & $\begin{array}{l}2069 \\
\text { Streptococcus gordonii str }\end{array}$ \\
\hline Serratia plymuthica AS9 & Sphingobacterium sp 21 & Challis substr $\mathrm{CHI}$ \\
\hline Serratia proteamaculans 568 & Sphingobium & Streptococcus macedonicus \\
\hline Serratia sp AS12 & chlorophenolicum L 1 & ACA DC 198 \\
\hline $\begin{array}{l}\text { Serratia symbiotica str Cinara } \\
\text { cedri }\end{array}$ & $\begin{array}{l}\text { Sphingobium japonicum } \\
\text { UT26S }\end{array}$ & $\begin{array}{l}\text { Streptococcus mitis B6 } \\
\text { Streptococcus mutans }\end{array}$ \\
\hline Shewanella amazonensis SB2B & Sphingobium sp SYK 6 & NN2025 \\
\hline Shewanella baltica OS155 & Sphingomonas wittichii RW1 & Streptococcus oralis Uo5 \\
\hline $\begin{array}{l}\text { Shewanella denitrificans } \\
\text { OS217 }\end{array}$ & $\begin{array}{l}\text { Sphingopyxis alaskensis } \\
\text { RB2256 }\end{array}$ & $\begin{array}{l}\text { Streptococcus parasanguinis } \\
\text { ATCC } 15912\end{array}$ \\
\hline $\begin{array}{l}\text { Shewanella } \\
\text { NCIMB } 400\end{array}$ & $\begin{array}{l}\text { Spirochaeta caldaria DSM } \\
7334\end{array}$ & $\begin{array}{l}\text { Streptococcus } \\
\text { KCTC } 11537\end{array}$ \\
\hline $\begin{array}{l}\text { Shewanella halifaxensis HAW } \\
\text { EB4 }\end{array}$ & $\begin{array}{l}\text { Spirochaeta } \quad \text { smaragdinae } \\
\text { DSM } 11293\end{array}$ & $\begin{array}{l}\text { Streptococcus } \\
\text { ATCC } 43144\end{array}$ \\
\hline Shewanella loihica PV 4 & Spirochaeta thermophila DSM & Streptococcus \\
\hline Shewanella oneidensis MR 1 & 6192 & ST556 \\
\hline $\begin{array}{l}\text { Shewanella pealeana ATCC } \\
700345\end{array}$ & Spirosoma linguale DSM 74 & $\begin{array}{l}\text { Streptococcus } \\
\text { pseudopneumoniae IS7493 }\end{array}$ \\
\hline
\end{tabular}


bioRxiv preprint doi: https://doi.org/10.1101/001727; this version posted January 10,2014 . The copyright holder for this preprint (which was not certified by peer review) is the author/funder, who has granted bioRxiv a license to display the preprint in perpetuity. It is made available under aCC-BY-NC-ND 4.0 International license.

SIANN: Strain Identification by Alignment to Near Neighbors

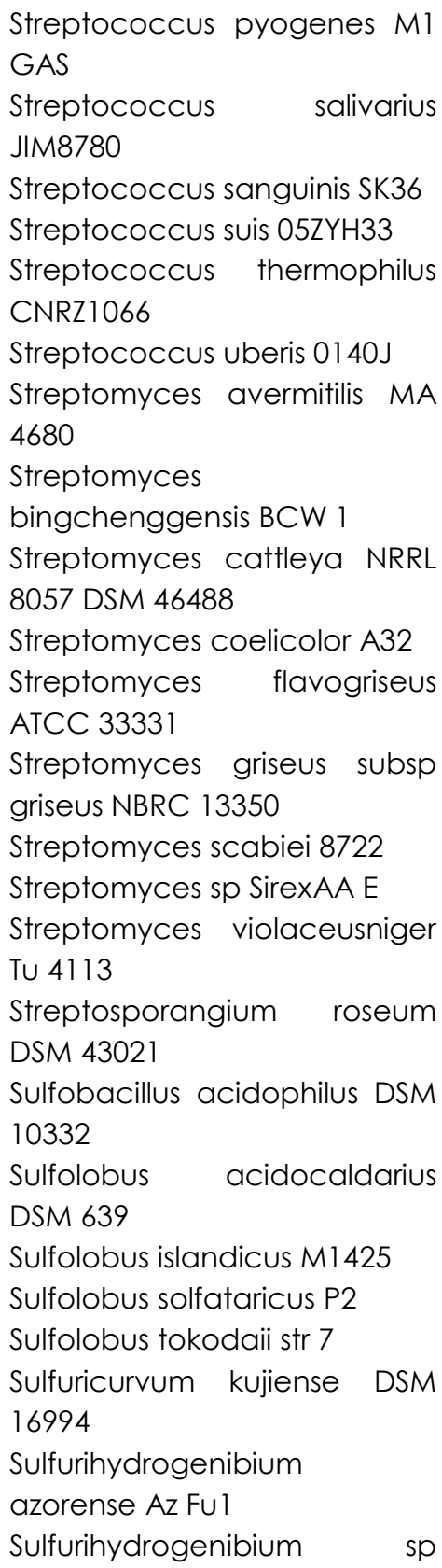

YO3AOP1

Sulfurimonas autotrophica

DSM 16294

Sulfurimonas denitrificans DSM 1251

Sulfurospirillum deleyianum

DSM 6946

Sulfurovum sp NBC37 1

Symbiobacterium

thermophilum IAM 14863

Synechococcus elongatus

PCC 6301

Synechococcus sp CC9605
Synechocystis sp PCC 6803

Syntrophobacter

fumaroxidans MPOB

Syntrophobotulus glycolicus

DSM 8271

Syntrophomonas wolfei subsp

wolfei str Goettingen

Syntrophothermus lipocalidus

DSM 12680

Syntrophus aciditrophicus SB

Tannerella forsythia ATCC 43037

Taylorella equigenitalis MCE9

Tepidanaerobacter

acetatoxydans $\operatorname{Re} 1$

Teredinibacter turnerae T7901

Terriglobus saanensis SPIPR4

Tetragenococcus halophilus

Thavera sp MZIT

Thermaerobacter marianensis

DSM 12885

Thermanaerovibrio

acidaminovorans DSM 6589

Thermincola potens JR

Thermoanaerobacter brockii

subsp finnii Ako 1

Thermoanaerobacter italicus

Ab9

Thermoanaerobacterium

thermosaccharolyticum DSM

571

Thermoanaerobacterium

xylanolyticum LX 11

Thermoanaerobacter

mathranii subsp mathranii str

A3

Thermoanaerobacter

pseudethanolicus ATCC

33223

Thermoanaerobacter sp X513

Thermoanaerobacter

tengcongensis MB4

Thermoanaerobacter wiegelii

R+8B 1

Thermobaculum terrenum

ATCC BAA 798

Thermobifida fusca YX

Thermobispora bispora DSM

43833

Thermococcus barophilus MP
Thermococcus

gammatolerans EJ3

Thermococcus kodakarensis

KOD 1

Thermococcus onnurineus

NAl

Thermococcus sibiricus MM

739

Thermococcus sp 4557

Thermocrinis albus DSM 14484

Thermodesulfatator indicus

DSM 15286

Thermodesulfobacterium $\mathrm{sp}$

OPB45

Thermodesulfobium

narugense DSM 14796

Thermodesulfovibrio

yellowstonii DSM 11347

Thermofilum pendens Hrk 5

Thermomicrobium roseum

DSM 5159

Thermomonospora curvata

DSM 43183

Thermoplasma acidophilum

DSM 1728

Thermoplasma volcanium

GSS 1

Thermoproteus uzoniensis 768

20

Thermosediminibacter oceani

DSM 16646

Thermosipho africanUs TCF52B

Thermosipho melanesiensis

BI429

Thermosphaera aggregans

DSM 11486

Thermosynechococcus

elongatus BP 1

Thermotoga lettingae TMO

Thermotoga maritima MSB8

Thermotoga naphthophila

RKU 10

Thermotoga neapolitana DSM

4359

Thermotoga petrophila RKU 1

Thermotoga sp RQ2

Thermotoga thermarum DSM

5069

Thermovibrio ammonificans

HB 1

Thermovirga lienii DSM 17291 
bioRxiv preprint doi: https://doi.org/10.1101/001727; this version posted January 10,2014. The copyright holder for this preprint (which was not certified by peer review) is the author/funder, who has granted bioRxiv a license to display the preprint in perpetuity. It is made available under aCC-BY-NC-ND 4.0 International license.

SIANN: Strain Identification by Alignment to Near Neighbors

Thermus scotoductus SA 01

Thermus sp CCB US3 UF1

Thermus thermophilus HB27

Thioalkalimicrobium cyclicum

ALM1

Thioalkalivibrio sp K90mix

Thioalkalivibrio sulfidophilus $\mathrm{HL}$

EbGr7

Thiobacillus denitrificans

ATCC 25259

Thiomicrospira crunogena

XCL 2

Thiomonas intermedia $\mathrm{K} 12$

Tolumonas auensis DSM 9187

Treponema azotonutricium

ZAS 9

Treponema brennaborense

DSM 12168

Treponema denticola ATCC 35405

Treponema pallidum subsp pallidum str Nichols

Treponema paraluiscuniculi

Cuniculi A

Treponema primitia ZAS 2

Treponema succinifaciens

DSM 2489

Trichodesmium erythraeum

IMS101

Tropheryma whipplei str Twist

Truepera radiovictrix DSM

17093

Tsukamurella paurometabola

DSM 20162

Ureaplasma parvum serovar 3

str ATCC 27815

Ureaplasma urealyticum

serovar 10 str ATCC 33699

Variovorax paradoxus $\$ 110$

Veillonella parvula DSM 2008

Verminephrobacter eiseniae

EFO1 2

Verrucosispora maris $A B \quad 18$

032

Vibrio anguillarum 775

Vibrio cholerae O1 biovar El

Tor str N16961

Vibrio fischeri ES 114

Vibrio furnissii NCTC 11218

Vibrio harveyi ATCC BAA 1116
Vibrio parahaemolyticus RIMD

2210633

Vibrio sp EJY3

Vibrio splendidus LGP32

Vibrio vulnificus CMCP6

Vulcanisaeta distributa DSM

14429

Vulcanisaeta moutnovskia

76828

Waddlia chondrophila WSU

861044

Weeksella virosa DSM 16922

Weissella koreensis KACC

15510

Wigglesworthia glossinidia

endosymbiont of Glossina

brevipalpis

Wolbachia endosymbiont of

Culex quinquefasciatus Pel

Wolbachia sp wRi

Wolinella succinogenes DSM

1740

Xanthobacter autotrophicus

Py2

Xanthomonas albilineans GPE

PC73

Xanthomonas axonopodis pv

citri str 306

Xanthomonas campestris pv

campestris str 8004

Xanthomonas oryzae pv

oryzae KACC 10331

Xenorhabdus bovienii SS 2004

Xenorhabdus nematophila

ATCC 19061

Xylanimonas cellulosilytica

DSM 15894

Xylella fastidiosa 9a5c

Yersinia enterocolitica subsp

enterocolitica 8081

Yersinia pestis $\mathrm{CO} 22$

Yersinia pseudotuberculosis IP

32953

Zobellia galactanivorans

Zunongwangia profunda SM

A87

Zymomonas mobilis subsp

mobilis ATCC 10988 